\title{
Review \\ Cyanobacteria: A Natural Source for Controlling Agricultural Plant Diseases Caused by Fungi and Oomycetes and Improving Plant Growth
}

\author{
Hillary Righini ${ }^{1}\left(\mathbb{D}\right.$, Ornella Francioso ${ }^{1} \mathbb{D}$, Antera Martel Quintana ${ }^{2}{ }^{(\mathbb{D}}$ and Roberta Roberti ${ }^{1, *}$ \\ 1 Department of Agricultural and Food Sciences, Alma Mater Studiorum, University of Bologna, \\ Viale G. Fanin, 40, 40127 Bologna, Italy; hillary.righini2@unibo.it (H.R.); ornella.francioso@unibo.it (O.F.) \\ 2 Banco Español de Algas, Instituto de Oceanografía y Cambio Global, IOCAG, Universidad de Las Palmas de \\ Gran Canaria, 35214 Telde, Spain; amartel@marinebiotechnology.org \\ * Correspondence: roberta.roberti@unibo.it
}

Citation: Righini, H.; Francioso, O.; Martel Quintana, A.; Roberti, R.

Cyanobacteria: A Natural Source for Controlling Agricultural Plant Diseases Caused by Fungi and Oomycetes and Improving Plant Growth. Horticulturae 2022, 8, 58 . https://doi.org/10.3390/

horticulturae 8010058

Academic Editors:

Jelena Popović-Djordjević and Luiz Fernando Cappa de Oliveira

Received: 29 October 2021

Accepted: 1 January 2022

Published: 8 January 2022

Publisher's Note: MDPI stays neutral with regard to jurisdictional claims in published maps and institutional affiliations.

Copyright: (C) 2022 by the authors. Licensee MDPI, Basel, Switzerland. This article is an open access article distributed under the terms and conditions of the Creative Commons Attribution (CC BY) license (https:// creativecommons.org/licenses/by/ $4.0 /)$.

\begin{abstract}
Cyanobacteria, also called blue-green algae, are a group of prokaryotic microorganisms largely distributed in both terrestrial and aquatic environments. They produce a wide range of bioactive compounds that are mostly used in cosmetics, animal feed and human food, nutraceutical and pharmaceutical industries, and the production of biofuels. Nowadays, the research concerning the use of cyanobacteria in agriculture has pointed out their potential as biofertilizers and as a source of bioactive compounds, such as phycobiliproteins, for plant pathogen control and as inducers of plant systemic resistance. The use of alternative products in place of synthetic ones for plant disease control is also encouraged by European Directive 2009/128/EC. The present up-to-date review gives an overall view of the recent results on the use of cyanobacteria for both their bioprotective effect against fungal and oomycete phytopathogens and their plant biostimulant properties. We highlight the need for considering several factors for a proper and sustainable management of agricultural crops, ranging from the mechanisms by which cyanobacteria reduce plant diseases and modulate plant resistance to the enhancement of plant growth.
\end{abstract}

Keywords: cyanobacteria; plant pathogens; fungi; oomycetes; antifungal activity; biocontrol; plantinduced resistance; plant biostimulants; cyanobacteria cultivation

\section{Introduction}

Cyanobacteria are a group of ancient microorganisms that appeared about 2.6-3.5 billion years ago [1]. They were responsible for the Great Oxygenation Event [2] during the Paleoproterozoic era, which radically changed the composition of the Earth's life forms and enabled the subsequent development of multicellular life forms [3]. It is assumed that during the evolution, plant plastids, cellular organelles in charge of photosynthesis, originated from cyanobacteria acquired through a process called endosymbiosis [4]. Cyanobacteria are also improperly called blue-green algae on the basis of their color, even though scientists have included them in the Cyanobacteria phylum of the bacteria domain. Cyanobacteria are the only prokaryota that can photosynthesize by using sunlight, water, and carbon dioxide to produce oxygen and energy. They form a monophyletic group with a high diversity in terms of morphology, physiology, and metabolic and molecular properties as a result of extensive time to colonize and adapt to evolving niches that emerge on Earth $[1,5,6]$. They are found worldwide in almost all environments (e.g., oceans, brackish water, freshwater, rocks, soil, plants, animals), many of which are extreme habitats where they play a prominent role [7-10].

Cyanobacteria have a high rate of adaptation to fluctuating environmental conditions, and pressure from competing organisms and grazers implies several survival mechanisms, including the production of secondary metabolites that are interesting for biotechnology applications [11-13]. Recent advances in genetic and metabolic engineering technologies have 
shown substantial progress in research aimed at realizing the full potential of cyanobacteria. Toxins naturally present in cyanobacterial cells may reach concentrations that pose a risk to human and animal health [14] due to the cyanobacteria's ability to produce a wide range of bioactive compounds, some of which are considered toxic (cyanotoxins). By contrast, the property of producing substances with antiviral, antimicrobial, anticancer, antioxidant, and anti-inflammatory activity with potential beneficial effects on human health has long been known [14-16]. Additionally, cyanobacteria also produce a variety of enzymes (chitosanase, protease, xylanase, and cellobiase) with antifungal activity and twenty-four families of protease inhibitors involved in several human, animal, and plant metabolic pathways $[14,17]$.

The interest in cyanobacteria is increasing, as shown by numerous studies in many fields, with more than 49,000 scientific documents that are cited in the Scopus database (Figure 1a). More than 1500 documents are cited in each of the following area: Agricultural and Biological Sciences, Biochemistry, Genetics and Molecular Biology, Environmental Science, Immunology and Microbiology, Earth and Planetary Sciences, Medicine, Chemistry, Pharmacology, Toxicology and Pharmaceutics, Multidisciplinary, Chemical Engineering, and Engineering (Figure 1b).

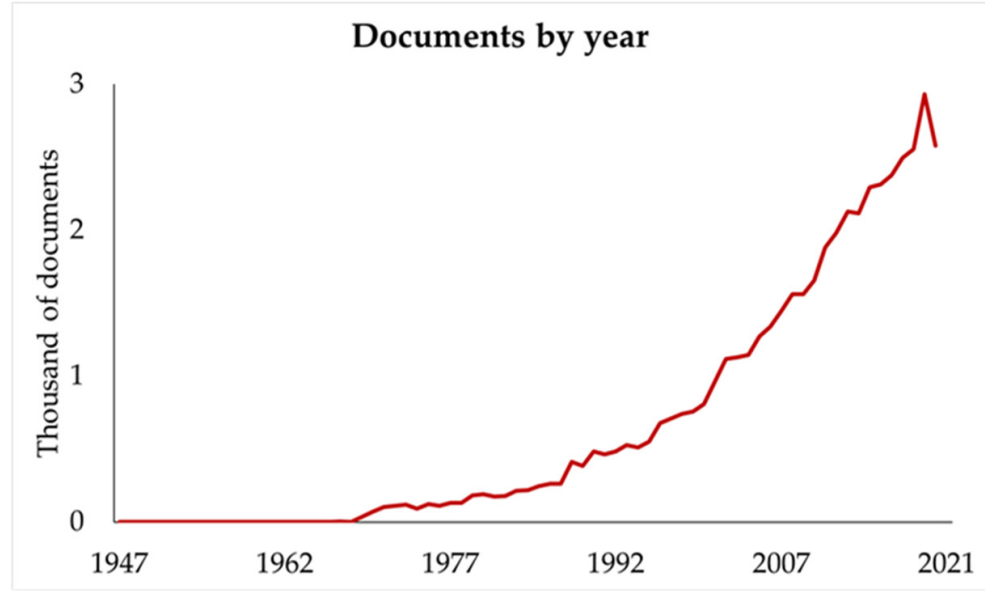

(a)

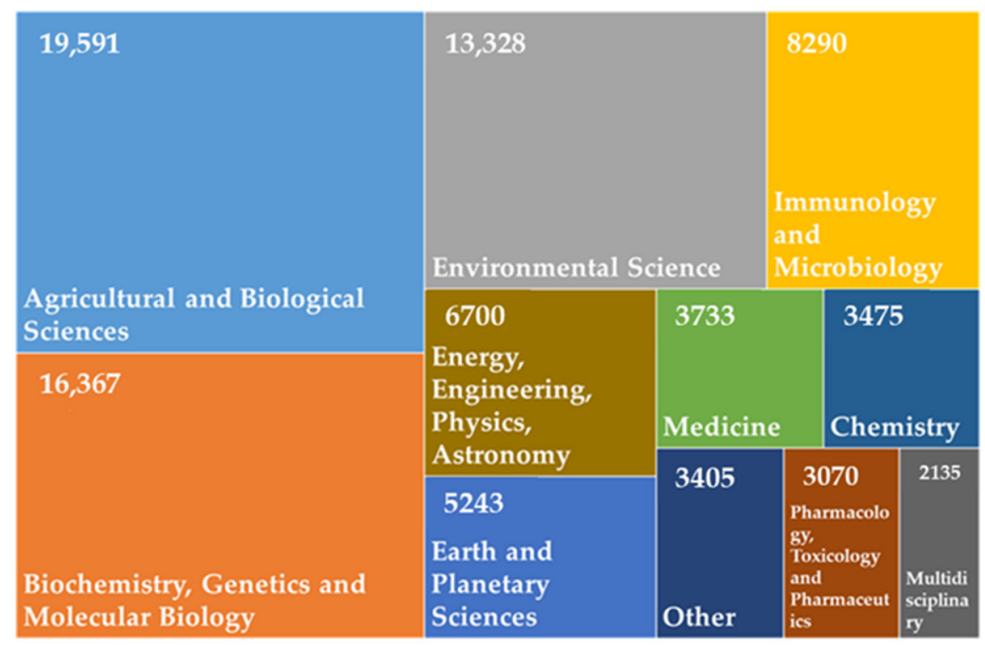

(b)

Figure 1. Scientific documents on cyanobacteria by year (a) and by subject area (b) reviewed in the Scopus ${ }^{\circledR}$ database (updated to October 2021). Other: Materials Science, Computer Science, Social Sciences, Mathematics, Neuroscience, Health Professions, Veterinary, Arts and Humanities, Decision Sciences, Economics, Econometrics and Finance, Business, Management and Accounting, Nursing, Psychology, Dentistry, Undefined. 
As reported by the Scopus ${ }^{\circledR}$ database (Figure 1b), scientific reports on cyanobacteria primarily cover the agricultural and biological sciences topic area, although some topic areas may overlap. More specifically, most articles refer to the biostimulant effect, as these microorganisms are a source of macro- and micronutrients, bioactive molecules, and plant hormones that may positively influence the plant [18]. More recently, only a few dozen articles referring to the effect of cyanobacteria on plant pathogens were cited in the Scopus database (search for "cyanobacteria + versus + plant pathogens"). Cyanobacteria have been shown to reduce the infection of several fungal pathogens by acting directly against pathogen growth and indirectly stimulating plant defense responses [19-22]. Recent studies have shown that Anabaena minutissima treatment elicits tomato root defense barriers through the production of phenolic compounds [20], protects cutin and pectin structures in tomato fruits from the etiological agent of gray mold disease (Botrytis cinerea) [23], and elicits the expression of pathogenesis-related genes in cucumber plants [24]. Consequently, cyanobacteria may potentially be an effective alternative to synthetic agrochemicals, which are currently the principal products for plant protection against pathogens, notably fungi and oomycetes. This is consistent with national and international regulations limiting the use of synthetic agrochemicals due to their harmful consequences on human and animal health and the environment.

The present review is aimed to contribute to the knowledge of cyanobacteria by providing their potential role in agriculture, in line with the most recent research. Firstly, several aspects of cyanobacteria in relation to their cultivation and extraction methods, as well as an overview of their general uses and toxicity are presented. Then, the role of cyanobacteria in the control of plant pathogens and in stimulating plant growth, and the current market and regulations of cyanobacteria-based products are discussed. This review highlights the need for considering several factors for a proper and sustainable management of agricultural crops, from the mechanisms by which cyanobacteria reduce plant diseases and modulate plant resistance to the enhancement of plant growth. Despite few scientific studies focus on the activity of cyanobacteria as both viable cells and extract against plant diseases, cyanobacteria are very important sources for the discovery and exploitation of antimicrobial compounds in phytopathology. Thus, they may be potential alternative tools to synthetic agrochemicals, necessary for preserving the environment, human and animal health, which is recommended by international rules.

\section{Cultivation, Growth, and Extraction Methods}

Cyanobacteria usually grow faster than plants and have a relatively small and simple genetic background that eases manipulation $[25,26]$. However, the success of the industrial scale exploitation of cyanobacteria in achieving sustainable yield of biomass and metabolites depends on (i) the selected strain, mainly based on robustness and composition anticipated level of valuable specialty product; (ii) the efficiency of the cultivation system; and (iii) the downstream processing which involves cell harvesting, drying, and biomass processing [27].

A large number of cultivation systems have been developed for phototrophic production of cyanobacteria, using either natural or artificial irradiance [28-30]. In any cultivation system, several basic variables have to be considered to optimize the growth of the strains: light quality and intensity, $\mathrm{pH}$, gas $\mathrm{CO}_{2} / \mathrm{O}_{2}$ exchange, nutrient supply, culture turbulence, light/dark cell cycling, biomass density, and culture depth (light path) (Figure 2). Cyanobacteria mass production can be performed in two basic cultivation systems: one being open reservoirs (raceway type or open circular ponds/tanks), while the other consists of closed transparent containers named Photobioreactors (PBR) (Figure 2) with natural or artificial illumination where the culture is protected from any microbial contamination source. Generally, open systems are cheaper and easy to operate on a large-scale production but suitable for a limited number of robust strains, because they are subjected to different sources of contamination and poor irradiation. Therefore, open systems could give low production. On the other hand, PBR offer a close and controlled system where 
culture conditions such as temperature, salinity, and light can be regulated to obtain high chemical composition and quality of the biomass $[30,31]$. Therefore, it is crucial to analyze the variables affecting the cultivation of a selected strain and consider possible pros and cons of a particular cultivation system and the expected value of the final product [30]. Once the optimal production is achieved, the cells are harvested, separated from their culture medium to obtain a concentrated biomass slurry or a cake with a reduced water content to enable downstream processes (Figure 3). The choice of harvesting techniques primarily depends on the morphology and size of the strain, the density of the culture and the desire final product [27]. The most extended methods for harvesting are filtration, centrifugation, flocculation, flotation, and sedimentation [27,32]. Forthwith, the biomass needs to be dried to avoid degradation of algal quality [32]. The technique applied varies according to the quality and quantity of the final product, the scale and the relation of the capital and production costs in terms of capital investment and the energy requirement. Drying accounts for 70 to $75 \%$ of processing costs [33]. However, efficient and cost-effective drying procedures for cyanobacteria have a large impact on both overall energy consumption and manufacturing cost of the end-product. Three dehydration methods are mainly used: sun-drying, spray-drying, and freeze-drying. Finally, the bioactive compounds are extracted. The cell walls are lysed by mechanical, chemical, and biological techniques to release the bioactive compounds, after which they are isolated and purified by complex methods and specialized equipment and, in many cases, toxic organic solvents are used in large quantities [34]. Therefore, sustainable extraction and purification techniques are being considered to minimize the environmental footprint and the economic impact in the end-product. Among the green extraction techniques, are used the supercritical fluid, pressurized liquid, ultrasound-assisted, microwave-assisted, and the pulse electric field [34]. In addition, the use of non-toxic and recyclable solvents, such as ionic liquids, surfactants, and alcohols in aqueous solution, that also show the potential to disrupt the cells, promote more effective extraction/purification methodologies with higher recoveries of the requested bioactive compounds desire [35,36].
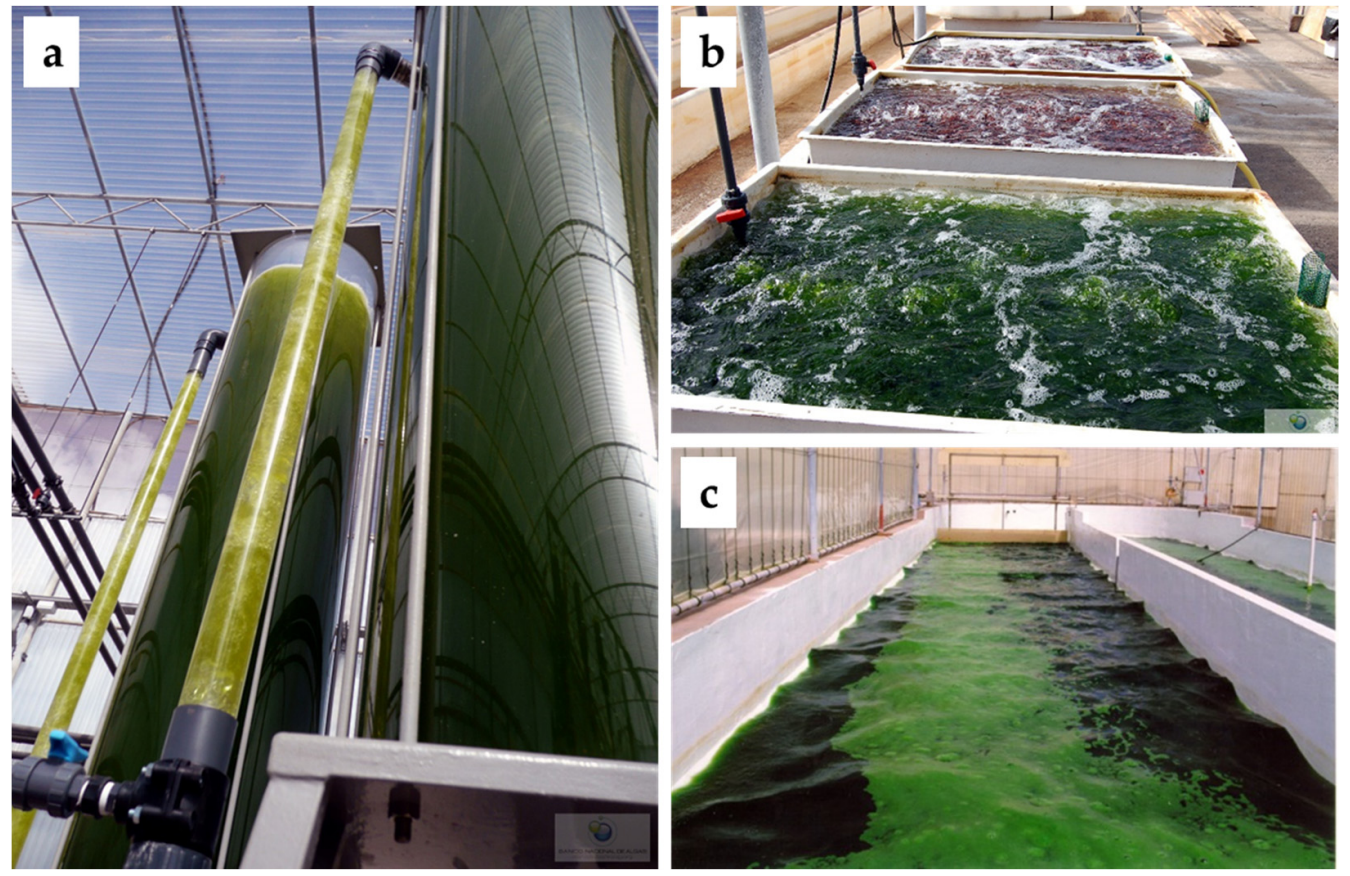

Figure 2. Examples of cyanobacteria cultivation systems: (a) photobioreactor; (b) tanks; (c) raceway at the Banco Español de Algas (BEA) experimental plant of microalgae (Courtesy: BEA). 


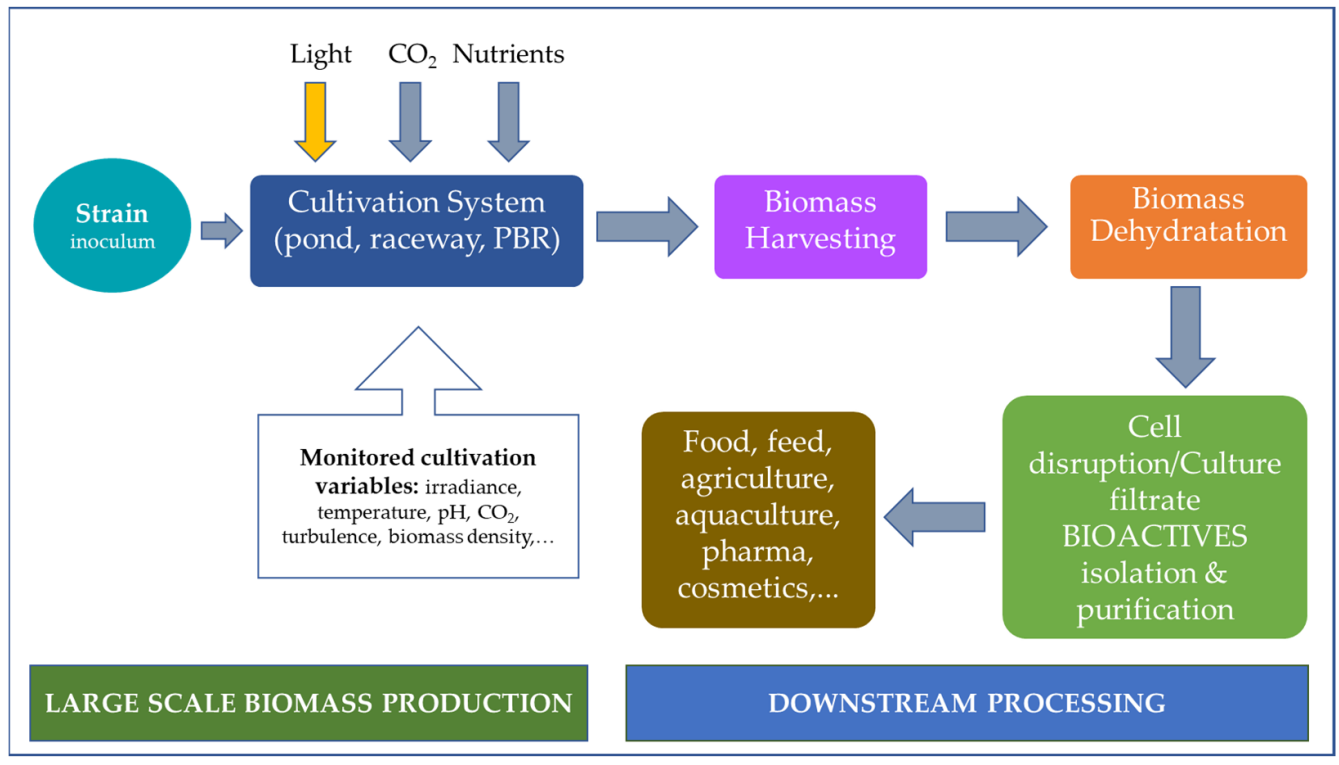

Figure 3. A schematic diagram of cyanobacteria cultivation and downstream processing.

\section{General Uses}

Cyanobacteria are often called "sustainable biofactories" for their sunlight-driven conversion of $\mathrm{CO}_{2}$ into a renewable resource of high-value industrial products [37]. It is known that cyanobacteria synthesis pigments, lipids proteins, polysaccharides, and other compounds with proven bioactivity [38,39]. In addition to that, cyanobacteria have the ability to perform different ways of metabolism and the capacity to quickly switch from one to another as survival mechanisms of adaptation to extreme irradiation, temperature, $\mathrm{pH}$, or salinity conditions generating a wide range of biologically active secondary metabolites [40-44]. More than two thousand secondary metabolites from cyanobacteria have been identified to date [45]. Structurally, the compounds range from low molecular weight, such as: alkaloids, sesterterpenoids, peptides, polyketides, porphinoids, terpenoids, and volatile alkanes $[46,47]$ to more complex, such as cyanotoxins [41]. Therefore, cyanobacteria devote a large part of their genome to the production of such metabolites due to the ability to combine genes encoding non-ribosomal peptide synthetases (NRPS) and polyketide synthases (PKSs) through enzymatic reactions, such as methylations, oxidations, reductions, and other chemicals modifications $[42,48]$. These metabolites have a broad range of commercial applications in numerous industries including pharmaceuticals, nutraceuticals, cosmeceuticals, biofuels, biofertilizers, wastewater treatments, food, and feed (Figure 4). As examples, cyanobacteria are source of exopolysaccharides with exceptional properties as food additives, biostimulants and soil conditioners in agriculture, biopolymers, bioadhesives, bioflocculants [49-51], anti-viral, mycosporine-like amino acid, and scytonemin $[14,52]$. Other valuable compounds are carotenoids, phycobiliproteins, and polyphenols which are used in cosmetic and cosmeceutical industries as sun blockers and anti-ageing for preventing the formation of wrinkles and skin sagging [38,53,54]. In the therapeutic and pharmaceutical application, the chemical and biological diversity of cyanobacteria make them an extraordinary resource for the discovery of new drugs. In the last decades, a considerable increase in the number of preclinical anticancer research has led to the discover of compounds derived from different species that have been applied into human clinical trials [41]. Further, a large number of new and biomolecules from cyanobacteria have shown immunosuppressant, anticancer, antibacterial, antiprotozoal, antifungal, anti-inflammatory, antimalarial, anticoagulant, anti-tuberculosis, and antiviral activities [16,40,55-59]. 


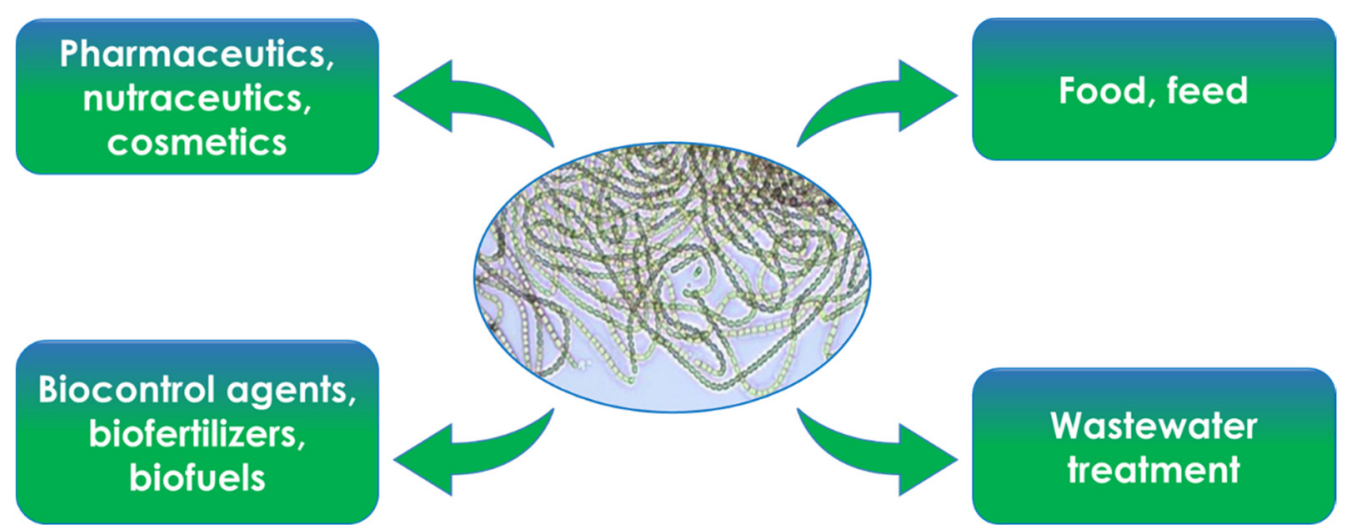

Figure 4. Overview of cyanobacteria general uses. Micrograph courtesy of Banco Español de Algas (BEA).

\section{Toxins}

Cyanobacteria are capable of producing a wide range of potent toxins as secondary metabolites [14,60]. It is estimated that 40 genera, of the 150 genera included in the cyanobacteria phylum, can produce toxins when forming blooms, in quantity causing acute and (sub)chronic poisonings of wild/domestic animals and humans [61,62]. The main genera producing toxins are Aphanizomenon, Cylindrospermopsis, Dolichospermum (previously Anabaena), Lyngbya, Microcystis, Nostoc, and Planktothrix [63]. These compounds differ in chemical structure (alkaloids, lipids, or cyclic peptides) and toxic effects (cytotoxic, dermatotoxic, hepatotoxic, and neurotoxic effects [64-67]. The cyclic peptides include microcystins and nodularins, while the alkaloids comprise anatoxin-a, anatoxin-a(S), cylindrospermopsin, saxitoxins (STXs), aplysiatoxins, and lyngbyatoxin [60].

In this review, the toxic effect of cyanotoxins is mainly focused on plants. There is an increasing attention in the use of cyanotoxin-contaminated surface waters for agricultural practices $[65,68,69]$. This issue may raise concerns about possible effects on crop growth and development due to bioaccumulation of toxins in the crops and thereby, the food security. Regarding the effects of cyanotoxins on plants, large amount of recent scientific articles have been published to explain the biochemical and physiological alterations induced by microcystins and cylindrospermopsins $[65,68-71]$. Structural and physiological alterations have crucial consequences on plant growth and on the crop productivity. The cyanotoxins induce considerable modification in the organization of plant-specific structures differently by the effects observed on animal/human cells $[69,71]$. A meta-analysis study on data published up to now on 35 crop plants, found that leafy greens, such as parsley and cabbage, accumulate about three times more microcystins in their edible portion than other agricultural crops [72]. Particular attention was paid to relate the response of plants to the concentration of microcystins. The study revealed that the adverse effects of microcystins in plants were amplified at high concentrations. An alteration in morphological parameters, estimated to be approximately $15-30 \%$, was experienced at low doses of toxin ( 1 to $10 \mu \mathrm{g} / \mathrm{L}$ ). The alteration percentage value has reached more than $60 \%$ in plants treated with toxin doses from 10 to $100 \mu \mathrm{g} / \mathrm{L}$ [72]. The detrimental effect of high doses of cyanotoxin also occurred as cell death as in case of microcystins [71]. In other studies, it was observed in rice seedlings a negative exposure-response relationship between microcystin concentrations $(1,100,1000$, and $3000 \mu \mathrm{g} / \mathrm{L})$ and different plant growth parameters, such as root, stem, and leaf dry weight and plant height as a consequence of the toxin accumulation during the exposure [73].

Abe et al. [74] conducted one of the first studies on the adverse effects of microcystins on chloroplast function in bean (Phaseolus vulgaris) leaves. A rapid but reversible inhibition of photosynthesis was observed at $10^{-2} \mathrm{~mol} \mathrm{~m}^{-3}$ microcystins whereas a stable inhibition was seen at $10^{-1} \mathrm{~mol} \mathrm{~m}^{-3}$. Leaf necrosis was observed at higher concentrations but not below $10^{-2} \mathrm{~mol} \mathrm{~m}^{-3}$. This study suggested that microcystin affected photosynthesis 
with a reversible, short-term effect at a single application of low concentration and with an irreversible, long-term effect at high concentration with a single application or when multiple applications at low concentrations are used [74]. In most cases, the alterations may be directly related to the specific biochemical effects of cyanotoxins as inhibition of protein phosphatases 1 and 2A and of protein synthesis [70,75]. Cyanotoxins cause spindle abnormalities and mitotic spindle disruptions in several plant species leading to distorted organs and growth inhibition [69-71,76]. These alterations were triggered by a change in the phosphorylation status of proteins (e.g., microtubule associated proteins) that regulates spindle assembly and leads to abnormal segregation of sister chromatids in mitosis [70,76]. Subcellular alterations induced by cyanotoxins, as shown above, generally anticipate the plant cell death [69]. Studies on cyanotoxin-induced cell death were reported for the first time in organs of Sinapis alba, P. vulgaris, and Brassica napus seedlings and potato shoot cultures [77]. In other studies, microcystin-induced oxidative stress in different plants prompted impairments in enzymatic and nonenzymatic ROS scavenger systems [78].

\section{Plant Pathogen Control}

The present review describes current knowledge on the activity described for cyanobacteria against a wide range of phytopathogenic fungi and oomycetes that attack agricultural plants.

\subsection{Plant Pathogens}

Plant pathogens are disease-causing agents belonging to several species of fungi, oomycetes (fungal-like organisms), bacteria, phytoplasmas, viruses, and nematodes. They are largely distributed in the environment and can affect plant root system, stem, leaf, and fruit of several crops in all cultivation systems causing considerable economic losses. The FAO estimation (2019) of plant diseases cost for the global economy is around USD 220 billion per year, with $20-40 \%$ of crop production lost to pests. Among the causal agents of infectious diseases, fungi are responsible of most of the diseases occurring in all agricultural crops [79]. Dean et al. [80] reviewed top 10 fungal plant pathogens on the base of scientific and economic relevance, such as Botrytis cinerea, Fusarium oxysporum, and Colletotrichum spp. Fungal diseases also constitute a concern for food security, because some fungi, as reported below, produce mycotoxins that are harmful for both human and livestock [81-83]. Oomycetes also include some of the most destructive plant pathogens, such as Phytophthora infestans, that is one of the major pathogens in potato production and Pythium spp. agents of damping-off in nursery [84]. Taking into account the above statements this review deals with cyanobacteria as biocontrol agents of plant pathogenic fungi and oomycetes.

In this section, both fungi and oomycetes studied for the activity of cyanobacteria are presented. Among fungi, Aspergillus and Fusarium species are the most considered. Aspergillus species are worldwide saprotrophic and pathogenic fungi. Many species that infect plants in the field can cause visible symptoms only during the postharvest stages. They attack fresh fruits and vegetables, dry fruit, grains, and cereal products. Many strains of Aspergillus produce mycotoxins, such as ochratoxin A (A. carbonarius, A. niger, A. parasiticus, and A. westerdijkiae), and aflatoxins (A. flavus) which are high toxic to mammals [81,85]. Some species are also opportunistic human and animal pathogens [86]. Fusarium oxysporum is a representative example of Fusarium species for studying cyanobacteria extracts activity. Fusarium oxysporum is a species complex including more than 150 different formae speciales adapted to infect specific host plants [87]. They are ubiquitous soil borne pathogens, responsible for a wide range of plant diseases and usually causing a vascular wilt with host-specific forms [88]. These pathogens penetrate the root epidermis and colonize the xylem vessels resulting in plant wilt and yellowing symptoms causing considerable crop losses [89]. Their control is difficult due to the lack of effective fungicides; hence, the research of new alternative solutions is gaining attention in sustainable agriculture. Infection by F. oxysporum can also be harmful to humans and animal health [90]. Other 
plant pathogens tested for the activity of cyanobacterial extracts are the fungi Penicillium expansum, P. verrucosum, Penicillium sp., Macrophomina phaseolina, Alternaria solani, A. alternata, Drechslera oryzae, Rhizoctonia solani, Botrytis cinerea, Armillaria sp., Rosellinia sp., Sclerotinia sclerotiorum, Verticillium albo-atrum, Colletotrichum gleosporioides, and C. musae. It is noteworthy that $P$. expansum has a wide host range, causing mainly post-harvest rot symptoms on fruits and produces the neurotoxin patulin, which can be taken by humans with apples and apple products [82]. Concerning oomycetes, Pythium aphanidermatum, P. debaryanum, P. ultimum, Phytophthora cambivora, P. capsici, and P. cinnamomic are studied for cyanobacteria activity. These pathogens survive in soil and can cause damping off in seedlings, root and crown rot, stunted growth, and wilting in many older agricultural plants. Moreover, P. capsici can infect leaf and fruit of major crop hosts (tomato, eggplant, all cucurbits, snap, and lima beans) [91] and P. cinnamomi together with P. cambivora can be pathogens of several forest trees [89].

Important fungal pathogens globally distributed are the soil borne Rhizoctonia solani and the foliar pathogens Botrytis cinerea and Podosphaea xanthii. Rhizoctonia solani causes damping-off of seedlings, root rot, and leaf blight [92] and under unfavorable environmental conditions produces resistant structures that can survive in the soil for several years and on debris from various cultivated plants [89]. Botrytis cinerea is one of the most widely studied fungal pathogens and causes serious disease, namely gray mold disease, on various economically important crops including strawberry, tomato, and grape [80]. This fungus is very aggressive and can infect stems, leaves, flowers, and fruits in pre- and post-harvest [93]. Botrytis cinerea has been recognized as one of the most important post-harvest pathogens in both fresh fruits and vegetables [80]. Podosphaera xanthii is the main causal agent of cucurbits powdery mildew spread worldwide [94]. Typical disease symptoms are whitish powdery mass mainly composed by mycelium and spores that mainly appear on leaf and stems. Under favorable environmental conditions, fungal colonies cover the entire upper leaf surface resulting in chlorosis and early senescence [95]. A worldwide pathogen causing severe damage on one of the most important crops is Magnaporthe oryzae, the agent of rice blast disease. This fungus causes necrotic symptoms on all parts of the plant and is responsible of 10-30\% rice global yield losses [96].

\subsection{Cyanobacteria as Biocontrol Agents}

\subsubsection{In Vitro Studies and Mechanisms of Fungal and Oomycete Growth Inhibition}

Many research papers demonstrate the activity of cyanobacterial extracts against fungal and oomycetes pathogens in agar medium assay (Table 1). Nostocales and Oscillatoriales orders are the most studied since the early 2000. Several extracts from Microcystis aeruginosa, Anabaena spp., Fischerella sp., Nostoc spp., Scytonema spp., Lyngbya lutea, Oscillatoria spp., Phormidium tenue, Trichodesmium hildebrantii, Synechococcus elongates, and Synechocystis sp. Inhibited Aspergillus spp. Mycelial growth in agar disk diffusion assay [97-100]. Fungal inhibition has consistently been shown by the methanol extract of these cyanobacteria $[97,98,100]$ and in some cases, depending on cyanobacterium species vs Aspergillus species, by extracts with acetone, diethyl ether, ethyl acetate, ethanol, methyl chloride, $n$-propanol, petroleum, and petroleum ether [97,100]. Activity against Aspergillus spp. Was also obtained with aqueous extract from Lyngbya lutea, Oscillatoria spp., Phormidium tenue, and Synechocystis sp. [100], and with Nostoc muscorum culture filtrate [99].

Regarding the growth reduction in Fusarium species, it was obtained by Microcystis aeruginosa, Anabaena spp., Calothrix brevissima, Nodularia sp., Nostoc spp., Lyngbya lutea, Oscillatoria spp., Phormidium spp., Trichodesmium hildebrantii, Synechococcus elongates, and Synechocystis sp. [17,21,22,97,99-104]. More specifically, the methanol extract from most cyanobacteria species (Nostoc spp., Lyngbya lutea; Oscillatoria spp., Phormidium spp., Trichodesmium hildebrantii, Synechococcus elongates, and Synechocystis sp.) showed efficacy in reducing Fusarium growth [100-104]. Extracts obtained with other organic solvents, such as n-propanol, petroleum ether, aceton, methyl chloride, diethyl ether, and ethyl acetate were also effective against Fusarium spp. [97,100]. Moreover, culture filtrates from several 
species of Anabaena and an aqueous extract from Phormidium tenue reduced Fusarium spp. growth $[21,22,100]$. In addition to inhibiting the growth of Aspergillus and Fusarium species, cyanobacteria extracts have shown efficacy against other plant pathogens (Table 1).

Table 1. Activity of extracts and culture filtrates from cyanobacteria against phytopathogenic fungi and oomycetes in agar medium assays.

\begin{tabular}{|c|c|c|c|}
\hline Cyanobacterium & Extract/Culture Filtrate ${ }^{1}$ & Plant Pathogen & Reference \\
\hline \multirow{7}{*}{$\begin{array}{l}\text { Chroococcales } \\
\text { Microcystis aeruginosa }\end{array}$} & & & \\
\hline & ME & Aspergillus carbonarius, A. niger & [97] \\
\hline & ETH & A. flavus, A. niger, A. parasiticus & \\
\hline & $\mathrm{AC}$ & A. flavus, A. niger, Fusarium proliferatum & \\
\hline & $\mathrm{MC}$ & A. flavus, A. parasiticus, F. proliferatum & \\
\hline & $\mathrm{DE}$ & $\begin{array}{l}\text { A. carbonarius, A. flavus, A. niger, A. ochraceus, A. westerdijkiae, } \\
\text { F. proliferatum, F. verticillioides, Penicillium verrucosum }\end{array}$ & \\
\hline & EA & A. carbonarius, A. flavus, A. niger, A. westerdijkiae, F. verticillioides & \\
\hline \multicolumn{4}{|l|}{ Nostocales } \\
\hline Anabaena spp. & CFILT & $\begin{array}{c}\text { Alternaria solani, Drechslera oryzae, Fusarium moniliforme, F. solani, } \\
\text { Macrophomina phaseolina, Pythium aphanidermatum }\end{array}$ & {$[17]$} \\
\hline Anabaena sp. & $\mathrm{PE}$ & Alternaria alternata & [101] \\
\hline Anabaena sp. & ME & Aspergillus flavus & [98] \\
\hline A. cylindrica & ME & A. flavus & [98] \\
\hline A. oscillarioides & CFILT, L & $\begin{array}{l}\text { F. moniliforme, F. oxysporum f. sp. lycopersici, Pythium debaryanum, } \\
\text { Rhizoctonia solani }\end{array}$ & {$[21]$} \\
\hline A. solitaria & ME & Alternaria alternata & [101] \\
\hline A. variabilis & CFILT, L & $\begin{array}{l}\text { F. moniliforme, F. oxysporum f. sp. lycopersici, P. debaryanum, } \\
\text { R. solani }\end{array}$ & [21] \\
\hline A. variabilis & CFILT & F. oxysporum f. sp. lycopersici & [22] \\
\hline A. laxa clones & CFILT & Pythium aphanidermatum & [105] \\
\hline \multirow[t]{2}{*}{ Calothrix brevissima } & PE & Alternaria alternata & [101] \\
\hline & ME & A. alternata, Botrytis cinerea, F. oxysporum & [101] \\
\hline Fischerella sp. & ME & Aspergillus flavus & [98] \\
\hline Nodularia sp. & ME & F. oxysporum & [101] \\
\hline Nostoc sp. & ME & A. flavus & [98] \\
\hline $\begin{array}{c}\text { Nostoc strain ATCC } \\
53789\end{array}$ & ME & $\begin{array}{c}\text { Armillaria sp., Fusarium solani, F. oxysporum f. sp. melonis, } \\
\text { Penicillium expansum, Phytophthora cambivora, P. cinnamomi, } \\
\text { Rhizoctonia solani, Rosellinia sp., Sclerotinia sclerotiorum, } \\
\text { Verticillium albo-atrum }\end{array}$ & [102] \\
\hline $\begin{array}{l}\text { Nostoc strain UTEX } \\
2493\end{array}$ & ME & Rosellinia sp. & {$[102]$} \\
\hline N. calcicula & ME & Aspergillus flavus & [98] \\
\hline N. commune & ME & F. oxysporum f. sp. lycopersici & [104] \\
\hline \multirow[t]{2}{*}{ N. commune } & $\mathrm{PE}$ & Phytophthora capsici, Pythium ultimum & [101] \\
\hline & ME & F. oxysporum, P. capsici & [101] \\
\hline N.commune & PE & Alternaria alternata & [101] \\
\hline \multirow[t]{2}{*}{ N.commune } & ME & A. niger & [100] \\
\hline & $\mathrm{PE}$ & A. flavus, $A$. niger & [100] \\
\hline N.entophytum & $\mathrm{AC}, \mathrm{CHL}, \mathrm{ME}$ & R. solani & [106] \\
\hline N. linckia & $\mathrm{ME}$ & F. oxysporum f. sp. lycopersici & [103] \\
\hline N.muscorum & $\mathrm{ME}$ & A. alternata, $B$. cinerea, Colletotrichum gleosporioides & [101] \\
\hline N.muscorum & CFILT & Aspergillus flavus, A. niger, Fusarium microsporium, Penicillium sp. & [99] \\
\hline N.muscorum & $\mathrm{AC}, \mathrm{CHL}, \mathrm{ME}$ & R. solani & [106] \\
\hline $\begin{array}{l}\text { Scytonema sp., } \\
\text { S. hofmanni }\end{array}$ & ME & A. flavus & {$[98]$} \\
\hline \multicolumn{4}{|l|}{ Oscillatoriales } \\
\hline Arthrospira platensis & PBPs & B. cinerea & [107] \\
\hline \multirow{3}{*}{ Lyngbya lutea } & W & A. niger & [100] \\
\hline & ME & A. niger, Colletotrichum musae, F. oxysporum & \\
\hline & nPROP & A. flavus, F. oxysporum & \\
\hline
\end{tabular}


Table 1. Cont.

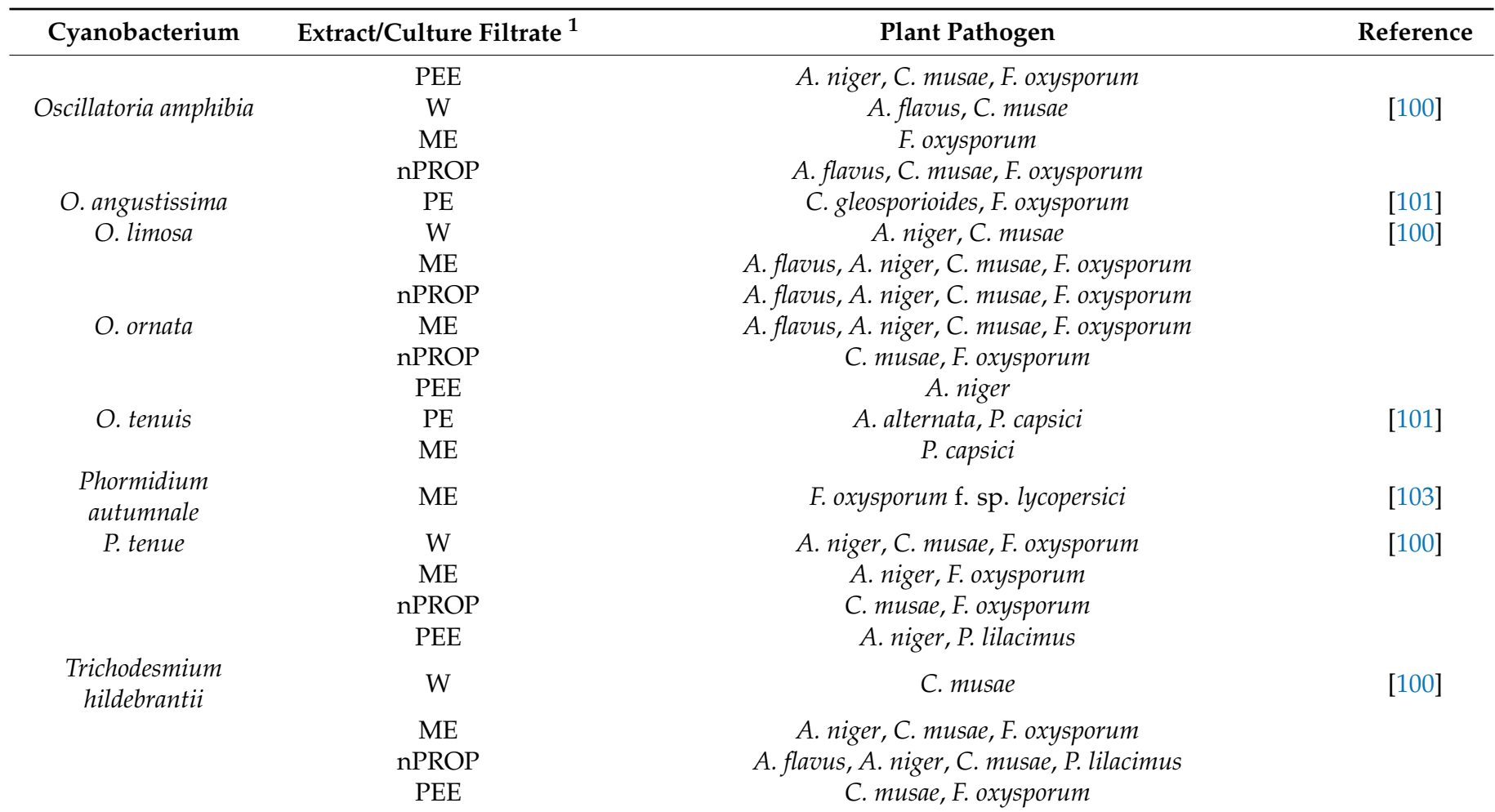

\begin{tabular}{|c|c|c|c|}
\hline Synechococcales & & & \\
\hline $\begin{array}{l}\text { Synechococcus } \\
\text { elongates }\end{array}$ & W & C. musae & [100] \\
\hline & ME & A. niger, C. musae, F. oxysporum & \\
\hline & nPROP & A. flavus, A. niger, P. lilacimus & \\
\hline & PEE & C. musae, F. oxysporum & \\
\hline Synechocystis sp. & $\mathrm{W}$ & A. flavus, A. niger, C. musae, P. lilacimus & [100] \\
\hline & $\mathrm{ME}, \mathrm{nPROP}$ & A. flavus, A. niger, C. musae, P. lilacimus, F. oxysporum & \\
\hline & PEE & C.musae & \\
\hline
\end{tabular}

Among Nostocales, methanol extracts from Nostoc spp. were efficient in reducing the colony growth of the fungi Armillaria sp., Rosellinia sp., Sclerotinia sclerotiorum, Penicillium expansum, Verticillium albo-atrum, and R. solani and of the oomycetes Phytophthora cambivora and P. cinnamomi $[102,106]$. Rhizoctonia solani and the oomycete Pythium debaryanum were also inhibited by Anabaena variabilis and A. oscillarioides culture filtrates and leachates from compost amended with each cyanobacterium viable cells [21]. Prasanna et al. [17] demonstrated that Anabaena spp. culture filtrates were effective against the fungi Macrophomina phaseolina, Drechslera oryzae, and Alternaria solani and against the oomycete Pythium aphanidermatum growth, while methanol extracts of Anabaena solitaria, Calothrix brevissima, and Nostoc muscorum reduced A. alternata [101]. The last two extracts showed efficacy also against $B$. cinerea, while the extract of $N$. commune was effective against Phytophthora capsici [101]. Culture filtrates of Anabaena laxa and N. muscorum reduced the oomycete P. aphanidermatum and the fungus Penicillium sp. growth, respectively $[99,105]$. The growth of a different species of Penicillium, P. verrucosum, was also reduced by a diethyl ether extract from Microcystis aeruginosa that belongs to Chroococcales order [97]. Among the extract of Oscillatoriales order, colony growth reduction in both fungi and oomycetes was obtained. A recent study showed that phycobiliproteins extracted from A. platensis hampered the germination of $B$. cinerea spores by inhibiting spore germination and mycelial development [107]. 
This pathogen produces a vast quantity of airborne spores which are the main fungus dispersal mean, therefore, the inhibition of spore germination can play a role in disease control by interrupting secondary infections. The antifungal activity of other kinds of proteins has been also demonstrated on B. cinerea spore germination, as well as on mycelial growth [108]. Arthrospira platensis proteins are characterized by a secondary $\alpha$-helix structure. This protein structure, being prominently represented in transmembrane proteins, could interact with the fungal cell wall, leading to the perturbation of cell activity [107]. A petrol extract from Oscillatoria angustissima inhibited Colletotrichum gleosporioides [101], while several kinds of extract from Oscillatoria spp., Phormidium tenue and Trichodesmium hildebrantii reduced the growth of Colletotrichum musae [100]. Moreover, Oscillatoria tenuis petroleum and methanol extracts reduced the growth of the oomycete Phytophthora capsici [101]. Colletotrichum musae was also inhibited by aqueous, methanol or petroleum ether extracts from the Synechococcales Synechococcus elongates and Synechocystis sp. [100].

The antifungal activity shown in Table 1 is mainly referred to cyanobacteria extracellular culture filtrates $[17,21,22,105]$ and to extracts obtained from cyanobacteria with different organic solvents, such as acetone, chloroform, diethyl ether, ethyl acetate, ethanol, methanol, methyl chloride, $n$-propanol, petroleum and petroleum ether [17,21,22,97-106], as well as water [100]. The culture filtrates are rich of many substances that can display interesting antifungal activity. In particular, up to 85 families of metabolites with high antimicrobial activity were isolated from various strains of cyanobacteria [14]. Culture filtrates of several Anabaena species with fungicidal activity produced one or more hydrolytic enzymes, such as proteases, chitosanases, exo- $\beta$-1,4-glucanases, and carboxy-methyl cellulase [17,105]. For Anabaena variabilis ATCC 29413, the gene putatively responsible for chitosanase and antifungal activities was attributed to the glycoside hydrolase 3-like family [105]. All these enzymes are known to be involved in the digestion of fungal or oomycetes cells. For example, chitosan and chitosan-glucan complexes were found in the mycelia of Aspergillus niger and Fusarium moniliforme [105]. The use of organic solvents in the extraction process, affects the antifungal activity of cyanobacterial extracts [100]. For example, in the extract of Microcystis aeruginosa obtained with diethyl ether were identified the butylated hydroxytoluene and methyl ester of hexadecanoic acid, which have antifungal activity against Aspergillus spp., Fusarium spp. and Penicillium sp. [97]. Another important antifungal activity against $A$. flavus was observed in the methanol extract of Anabaena spp., Nostoc sp. and Scytonema sp. The identification of the macrolide scytophycin and the presence of the glycolipopeptide hassallidin extracted from Anabaena strains elucidated the antifungal activity [98]. Osman et al. [106] suggested that phenols and polysaccharides contained in extracts from Nostoc spp. are involved in the antifungal activity against $R$. solani. From a previous study [99], a phenolic compound was isolated and purified from the chloroform extract of Nostoc muscorum with strong activity against Aspergillus niger, A. flavus, Pencillium sp., and Fusarium microsporium. Aqueous extracts have not been so widely investigated as the extracts obtained with organic solvents, even though they are safer for both human and environment. A recent study showed that soluble polysaccharides extracted from Anabaena minutissima aqueous extract reduced both colony growth and colony-forming units of B. cinerea [109]. In the same extract, proteins, phycobiliproteins, chlorophylls, carotenoids, and antioxidant activities were also determined and correlated with the antifungal effect against the pathogenic fungus Podosphaera xanthii on cucumber detached cotyledons in in vitro assay [24].

\subsubsection{In Vivo Studies and Mechanisms of Biocontrol Ability}

Most of the examples in Table 2 shows that extracts and compounds from cyanobacteria belonging to order of Nostocales are active against fungal pathogens mainly, whereas those from Oscillatoriales showed activity against fungi only.

Among Nostocales, the Anabaena species are widely studied. Both A. minutissima and A. variabilis were active in controlling foliar, soil-borne, or fruit pathogens [20-24,109,110]. An aqueous extract from $A$. minutissima sprayed on cucurbit plants reduced powdery 
mildew symptoms caused by P. xanthii under greenhouse conditions. On cucumber, the treatment reduced the diseased leaf area by $31 \%$ and the sporulation (spores $/ \mathrm{mm}^{2}$ ) by $47 \%$ [24], while on zucchini the disease reduction was $25 \%$ [110]. These activities were attributed to carotenoids, polysaccharides, chlorophylls, and proteins that were determined in the extract. The same extract applied on both cucurbits was able to elicit plant defense systemic responses in which enzyme activities and different expression of various pathogenesis related (PR) protein genes are involved (Figure 5). Plant responses to A. minutissima treatment are jasmonic acid (JA) and salicylic acid (SA) dependent. Indeed, activity and expression of total chitinases, $\beta$-1,3-glucanases and peroxidases, and AePR3 and PR1 gene expression were enhanced $[24,110]$. The elicitation of seedling defense responses might be correlated with the substances contained in the aqueous extract. It is also noteworthy that the same A. minutissima extract was a suitable mean for tomato seed treatment in controlling the soil-borne pathogen Rhizoctonia solani [20]. Additionally, on tomato, the extract elicited plant defense responses that were revealed by the increasing of chitinase activity and by lignin deposition in root seedlings. The cyanobacterium A. minutissima is also a source of bioactive compounds, such as polysaccharides and phycobiliproteins (PBPs). Polysaccharides applied by pre-harvest treatment to strawberry fruits reduced Botrytis cinerea symptoms and sporulation by $50 \%$ and $67 \%$, respectively [109]. As regard PBPs, they were able to reduce disease incidence and severity when applied on tomato fruits in a small-scale experiment [23]. The characterization of the tomato fruits by FT-IR and FT-Raman spectroscopic techniques revealed that $A$. minutissima PBPs preserved cutin and pectin structures by $B$. cinerea invasion. Concerning the effect of $A$. variabilis against pathogens, Chaudhary et al. [21] obtained the control of several fungi and of the oomycete $P$. debaryanum on tomato seedling by soil application of paddy straw compost amended with the cyanobacterium viable cells (Table 2 ). The same strain of $A$. variabilis applied as viable cells in a paddy straw compost-vermiculite was tested for suppressing wilt disease by $F$. oxysporum $\mathrm{f}$. sp. lycopersici on tomato seedling [22]. A low disease severity was observed, along with an increase in $\beta-1,3$ glucanases, polyphenol oxidases (PPO) and phenylalanine ammonia lyase (PAL) (Figure 5). Plant defense responses, such as peroxidases, and $\beta-1,3$ glucanases were also triggered in pathogen-unchallenged coriander, cumin, and fennel plants by another Anabaena species, A. laxa, and by Calothrix elenkinii, which were applied as biomass culture in a potting mix under controlled conditions [111]. Moreover, extracts from the same plants showed fungicidal activity against F. oxysporum in in vitro assay, suggesting a role of the plant enzymatic activities in the alteration of pathogen cell wall and membrane structures and functions.

Again on Nostocales (Table 2), Nostoc linkia added to soil controlled the soil-borne pathogen F. oxysporum f. sp. lycopersici in pot experiments [103]. In a more in-depth analysis regarding the mechanisms of Nostocales, the liquid medium culture of N. punctiforme showed to protect Arabidopsis thaliana cells from programmed cell death (PCD). The reduction in PCD by N. punctiforme was preceded by the induction of several WRKY family transcription factors [112]. This gene family is widely distributed in plants and play a key role in many metabolic pathways, including biotic and abiotic stress responses [113]. Soil drench treatment with viable cells of a consortium of Nostoc and Anabaena species, as well as C. elenkinii alone isolated from the rice phyllosphere was found effective against Magnaporthe oryzae on rice [114]. The same authors also demonstrated that these biocontrol agents were able to colonize plants, in particular the phyllosphere as resulted by the abundance of $16 \mathrm{~S}$ genes rRNA copies of the cyanobacterial communities. An important point to underline is that the isolates of Nostoc spp., Anabaena spp., and C. elenkinii have the same habitat of the pathogen $M$. oryzae, this suggesting a potential pathogen control on rice leaf. The effective treatments resulted in an increase in the leaf antioxidant enzymes PPO, PAL, peroxidases, phosphoenol pyruvate carboxylase activities involved in plant defense induction, for C. elenkinii, and an increase in only PPO for the consortium [114]. Again, on rice, the $C$. elenkinii inoculation in the seedling growth medium enhanced shoot and 
root defense enzyme activities, PPO, PAL, peroxidases, chitosanase, $\beta-1,3$ glucanases, and carboxymethyl cellulose [115] (Figure 5).

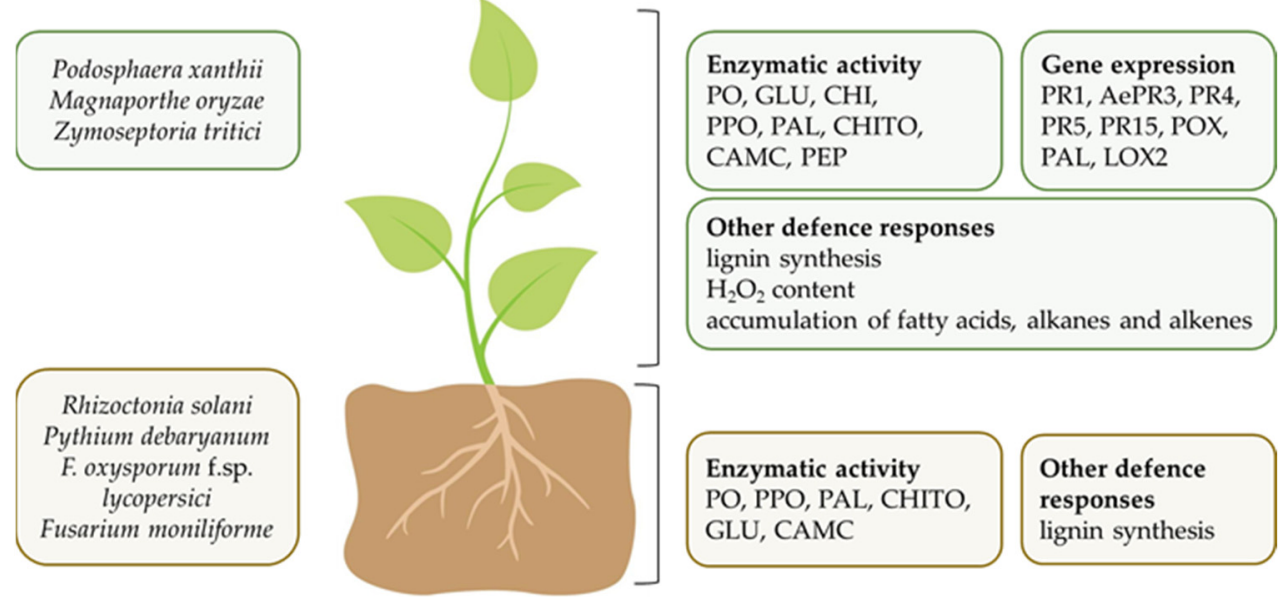

Figure 5. Foliar and soil-borne pathogens controlled by cyanobacteria application and plant defense responses in shoot and root induced by the cyanobacteria reported in this review. CAMC, carboxymethyl cellulose; CHI, chitinases; CHITO, chitosanase; GLU, $\beta$-1,3-glucanases; LOX, 13lipoxygenase 2; PAL, phenylalanine ammonia lyase; PEP, phosphoenolpyruvate carboxylase; PO, peroxidases; PPO, polyphenol oxidases; PR, pathogenesis related proteins; WRKY, family of transcription factors.

Table 2. Pathogen control and plant defence induction by cyanobacterial extracts and their single compounds applied on several plant species with different kind of treatments.

\begin{tabular}{|c|c|c|c|c|}
\hline Cyanobacterium & $\begin{array}{c}\text { Extract/ } \\
\text { Biomass/ } \\
\text { Compound }^{1}\end{array}$ & $\begin{array}{c}\text { Plant/ } \\
\text { Treatment }^{3}\end{array}$ & $\begin{array}{c}\text { Pathogen Control }{ }^{4 /} \\
\text { Plant Defense Responses }\end{array}$ & Reference \\
\hline \multicolumn{5}{|l|}{ Nostocales } \\
\hline Anabaena laxa & $\begin{array}{l}\text { Biomass } \\
\text { culture }\end{array}$ & $\begin{array}{l}\text { Coriander } \\
\quad \text { GS }\end{array}$ & Shoot and root: PO activity; shoot: GLU activity & [111] \\
\hline \multirow{8}{*}{ A. minutissima } & & $\begin{array}{l}\text { Cumin } \\
\text { GS }\end{array}$ & Shoot and root: $\mathrm{PO}$ activity & \\
\hline & & $\begin{array}{l}\text { Fennel } \\
\text { GS }\end{array}$ & Shoot: PO activity & \\
\hline & $W$ & Zucchini & Podosphaera xanthii (25\%) & [1100 \\
\hline & W & $\mathrm{L}$ & CHI, GLU, PO activity, isoforms of CHI, GLU, PO & {$[110]$} \\
\hline & W & $\begin{array}{l}\text { Cucumber } \\
\text { L }\end{array}$ & $\begin{array}{l}\text { P. xanthii }(31 \%) \\
\text { PR1, AePR3 genes }\end{array}$ & {$[24]$} \\
\hline & $\mathrm{W}$ & $\begin{array}{l}\text { Tomato } \\
\mathrm{S}\end{array}$ & $\begin{array}{l}\text { Rhizoctonia solani } \\
\text { Seedling: CHI activity, lignin content }\end{array}$ & {$[20]$} \\
\hline & PBPs & $\begin{array}{c}\text { Tomato } \\
\text { F }\end{array}$ & $\begin{array}{l}\text { Botrytis cinerea } \\
\text { cutin and pectin preservation }\end{array}$ & {$[23]$} \\
\hline & POL & $\begin{array}{l}\text { Strawberry } \\
\text { F }\end{array}$ & B. cinerea & [109] \\
\hline A. variabilis & Biomass $^{2}$ & $\begin{array}{l}\text { Tomato } \\
\text { GS }\end{array}$ & $\begin{array}{l}\text { Pythium debaryanum, } R \text {. solani, Fusarium moniliforme, F. } \\
\text { oxysporum f. sp. lycopersici }\end{array}$ & [21] \\
\hline A. variabilis & Biomass $^{2}$ & $\begin{array}{l}\text { Tomato } \\
\text { seedling }\end{array}$ & $\begin{array}{c}\text { F. oxysporum f. sp. lycopersici }(100 \%) \\
\text { GLU, PPO, PAL activity }\end{array}$ & [22] \\
\hline \multirow[t]{3}{*}{ Calothrix elenkinii } & $\begin{array}{l}\text { Biomass } \\
\text { culture }\end{array}$ & $\begin{array}{l}\text { Coriander } \\
\quad \text { GS }\end{array}$ & Shoot and root: $\mathrm{PO}$ activity & [111] \\
\hline & & $\begin{array}{l}\text { Cumin } \\
\text { GS }\end{array}$ & Shoot and root: PO activity & \\
\hline & & $\begin{array}{l}\text { Fennel } \\
\text { GS }\end{array}$ & Shoot: PO, GLU activity & \\
\hline
\end{tabular}


Table 2. Cont.

\begin{tabular}{|c|c|c|c|c|}
\hline Cyanobacterium & $\begin{array}{c}\text { Extract/ } \\
\text { Biomass/ } \\
\text { Compound }^{1}\end{array}$ & $\begin{array}{l}\text { Plant/ } \\
\text { Treatment } \\
3\end{array}$ & $\begin{array}{l}\text { Pathogen Control } 4 / \\
\text { Plant Defense Responses }\end{array}$ & Reference \\
\hline C. elenkinii & Biomass & $\begin{array}{l}\text { Rice } \\
\text { GS }\end{array}$ & $\begin{array}{c}\text { Shoot and root: PPO, PAL, PO, CHITO, GLU, CAMC } \\
\text { activity }\end{array}$ & [115] \\
\hline C. elenkinii & Biomass & $\begin{array}{l}\text { Rice } \\
\text { GS }\end{array}$ & $\begin{array}{c}\text { Magnaporthe oryzae }(50 \%) \\
\text { Leaf: PO, PPO, PAL, PEP activity }\end{array}$ & [114] \\
\hline Nostoc linkia & Biomass & $\begin{array}{l}\text { Tomato } \\
\text { GS }\end{array}$ & F. oxyporum f. sp. lycopersici & [103] \\
\hline N. punctiforme & $\begin{array}{l}\text { Medium } \\
\text { culture }\end{array}$ & $\begin{array}{l}\text { Arabidopsis } \\
\text { thaliana }\end{array}$ & WRKY & [112] \\
\hline $\begin{array}{l}\text { Nostoc-Anabaena } \\
\text { consortium }\end{array}$ & Biomass & $\begin{array}{l}\text { Rice } \\
\text { GS }\end{array}$ & $\begin{array}{l}\text { Magnaporthe oryzae }(69 \%) \\
\text { PPO activity }\end{array}$ & [114] \\
\hline \multicolumn{5}{|l|}{ Oscillatoriales } \\
\hline Arthrospira platensis & DB & $\begin{array}{l}\text { Wheat } \\
\text { L }\end{array}$ & $\begin{array}{c}\text { Zymoseptoria tritici }(\sim 70 \%) \\
\text { PR4, PR5, PR15, PO, PAL, LOX genes }\end{array}$ & [116] \\
\hline A. platensis & PBPs & $\begin{array}{l}\text { Tomato } \\
\text { F }\end{array}$ & B. cinerea & [107] \\
\hline A. platensis & POL & $\begin{array}{l}\text { Tomato } \\
\text { L }\end{array}$ & $\begin{array}{c}\text { PAL, CHI, GLU, PO activity; } \mathrm{H}_{2} \mathrm{O}_{2} \text { content; accumulation } \\
\text { of fatty acids, azelaic acid, alkanes, alkenes, other } \\
\text { metabolites }\end{array}$ & [117] \\
\hline \multicolumn{5}{|c|}{$\begin{array}{l}{ }^{1} \mathrm{~W} \text {, water extract; DB, dry biomass; PBPs, phycobiliproteins; POL, polysaccharides. }{ }^{2} \text { Biomass applied as viable } \\
\text { cells in paddy straw compost. }{ }^{3} \mathrm{~L} \text {, leaf; } \mathrm{S} \text {, seed; F, fruit, GS, plant growth substrate. }{ }^{4} \text { Disease reduction. }{ }^{5} \mathrm{CAMC} \text {, } \\
\text { carboxymethyl cellulose; CHI, chitinases; CHITO, chitosanase; GLU, } \beta-1,3 \text {-glucanases; LOX, } 13 \text {-lipoxygenase } 2 \text {; } \\
\text { PAL, phenylalanine ammonia lyase; PEP, phosphoenolpyruvate carboxylase; PO, peroxidases; PPO, polyphenol } \\
\text { oxidases; PR, pathogenesis related proteins; WRKY, family of transcription factors. }\end{array}$} \\
\hline
\end{tabular}

Concerning Oscillatoriales order, Arthrospira platensis (synonymous Spirulina platensis) sprayed on plants as dry biomass suspended in water, protected wheat plants from Zymoseptoria tritici in a similar way of the commercial product Bion ${ }^{\circledR} 50 \mathrm{WG}$, which is based on the elicitor acibenzolar-s-methyl [116]. In addition to the efficacy against this pathogen (about $70 \%$ with respect to the control), the treatment elicited wheat defenses by upregulating PR4, PR5, PR15 (oxalate oxidase), PAL, peroxidases, and mainly 13-lipoxygenase 2 genes. More recent research showed that $A$. platensis PBPs applied before Botrytis cinerea inoculation, controlled the pathogen on tomato fruit in a small-scale experiment. The PBPs characterization revealed an $\alpha$-helix secondary structure that is a class including transmembrane proteins, probably involved in the perturbation of fungal cell activity [107]. In tomato leaves, A. platensis polysaccharides induced many biochemical changes correlated to plant defense (PAL, chitinases, glucanases and peroxidases activities and $\mathrm{H}_{2} \mathrm{O}_{2}$ accumulation) and involved in the construction of wax and cutin, such as fatty acids (C16:3, C18:2 and C18:3, C18:0) and azelaic acid, alkanes (eicosane, tetracosane, octacosane, nonacosaene, triacontane, dotriacontane; the alkane derivate 1-chloroeicosane) and alkenes (1-octadecene, 1-pentadecene) [117]. Other new metabolites (2(4H)-benzofuranone, 5,6,7,7a-tetrahydro-4,4,7a-trim, neophytadiene, alpha-tocospiro-B, tris(2,4-di-tert-butylphenyl) phosphate) were also detected in the same leaves.

\section{Biostimulant Effects}

Recently, cyanobacteria have gained considerable attention as beneficial bioagents based on their ability to produce biomass for biofertilizers to be used in sustainable farming $[18,50,118]$. These organisms have been considered beneficial to soil fertility and crops through their ability to fix atmospheric nitrogen solubilize phosphate [119], produce bioactive substances, such as hormones (auxins, gibberellins, cytokinins) [120], polypeptides, amino acids [121], polysaccharides [122], and siderophores [123], having stimulatory effects on plants. Bioactive substances influence the expression of many genes in host plants, thereby boosting plant growth and helping plants to counteract both biotic and abiotic 
stresses $[18,50,118]$. In general, there is an improvement in plant physiological processes (Table S1), which facilitates nutrient uptake, yield, or fruit quality, while also improving the healthy environment [50]. Thus, the application of cyanobacteria in agriculture and environmental management includes: (i) economic benefits (lower production costs), (ii) improved nutrient cycling, (iii) water storage, and (iv) prevention of pollution and soil degradation, primarily through reduction in agrochemical use, nutrient recycling, and restoration of soil fertility through remediation [124]. The plant response is considerably influenced by the amount and concentration of bioactive molecules present in cyanobacteria which usually depends on the species and their growth conditions [50]. Several studies have found a dose-dependent response between cyanobacteria concentration and plant growth. As a consequence, the effects on plants are greater at low concentrations in terms of a higher fresh weight and chlorophyll content in radish seedlings after application of A. platensis [125]. Given the importance of cyanobacteria as biostimulants, they can play a key role in addressing sustainability challenges, as they can reduce mineral fertilizer inputs by encouraging the development of environmentally sustainable technologies.

The global market of biostimulants was valued at USD 2.6 billion in 2019 and is forecast to grow by $11.24 \%$ until 2025 [126]. In addition, the price of biostimulants ranges between EUR 10 and 80, and it varies by crop type, application timing, and dosage; the price of the application varies between EUR 100 and 600 per hectare [127]. The production of cyanobacterial biostimulants is limited, as these microorganisms are not currently listed in EU Regulation 2019/1009. Nerveless, Spain is the European Union leader in the cultivation and marketing of Arthrospira spp. as biostimulants. Thus, cyanobacteria-based biostimulant market remains a very small niche compared to the very high number of algae-based products that account for over $33 \%$ of the global market worldwide [128]. The updated list of cyanobacterial biostimulants currently on the market is reviewed by Santini et al. [18].

Nowadays, the cultivation of cyanobacteria for plant biostimulant production is quite expensive depending on the cultivation technology used (natural or artificial light, photobioreactors, or open ponds). Santini et al. [18] quote an extensive marketing analysis on the cost of treatment with cyanobacterial biostimulants, ranging from EUR 20 to 375 per hectare, depending on doses and number of applications. To make these biostimulants more market competitive, the cost of biomass production has to be reduced. To overcome some of the cost constraints of the process technology, an integrated biorefining concept should be applied to cyanobacterial biostimulant production [129]. This concept considers the sustainability of the entire process, from the use of non-potable water and recovery of nutrients from wastewater $(\mathrm{C}, \mathrm{N}, \mathrm{P})$ to eco-friendly end products, such as high-value compounds or the entire biomass [130] (SABANA H2020 Project). This also involves the reduction in the dehydration process, with the biomass being used directly in the process (SABANA H2020 Project). In particular, molecules with biostimulant activity may be extracted in biorefining process and the residual waste may be utilized as biofertilizer [131]. On the other hand, controlled cultivation and adaptability of cyanobacteria metabolism can provide a wide range of options for quality improvement and standardization of biostimulant production.

The application of cyanobacteria encompasses direct inoculation with living cells or extracts obtained by chemical, enzymatic, and mechanical/physical extractions, such as autoclaving, drying, heating with water after sonication, and cell destruction (grinding with pestle and blender) [18]. However, there is general evidence that the extraction method greatly influences the composition and bioactivity of the extracts. In general, cyanobacterial extraction procedures are more advantageous than using viable biomass as they allow for greater recovery of active ingredients contained in the cell or bound to the cell wall [18].

In order to provide cyanobacteria extracts or viable cells to crops, several application methods were adopted, depending on the cyanobacteria and their formulation. The most common treatments include: (i) soil amendment with dry biomass (e.g., powder, granules, or pellets) or suspended liquid culture, and (ii) foliar application by spraying leachate and supernatant [132]. The foliar spray application appears to be more efficient under 
high relative humidity conditions as leaf stomata are open, thus the product absorption is maximized.

Particularly interesting is the biostimulant effect of cyanobacteria on root development. Studies on several treated seedlings with cyanobacterial extracts showed significant changes in root architecture (higher total root length, surface, and number of root tips). The changes induced by cyanobacterial extracts reflected an enhancement in nutrients, water uptake and plant growth as observed on lettuce [133], tomato [134], red beet [133], and cucumber [135]. It is known that cyanobacteria excrete bioactive substances that act as signaling molecules, promoting plant growth and the synthesis of phytohormones such as IAA auxin, cytokinins, gibberellins, ethylene, jasmonic or abscisic acids $[136,137]$. These substances influence diverse physiological processes in plants, including stimulation of root growth and branching, seedling growth, flowering, and fruit ripening [138]. In addition, an influence is expected at the molecular level with an upregulation of several genes involved in the primary and secondary metabolic pathways [139].

Considering the large number of scientific papers on the beneficial effects of cyanobacteria on a variety of vegetables and crops, few studies have been conducted to identify the singular chemical constituents responsible for stimulating plant growth. Given the complex molecular mixtures present in cyanobacteria extracts, the identification of the role of single molecules in biological activity is very hard. However, synergistic action of several compounds in the mixture is known to boost the biostimulant activity [18]. Accordingly, research effort has been directed to identifying the mechanisms of action of cyanobacterial extracts, given their positive impact on plant productivity via enhancement of processes, such as photosynthesis, nutrient and water uptakes, and activation of resistance genes to abiotic stresses.

\section{Current Market and Regulations}

Cyanobacteria are sources of several bioactive compounds and thus employed in a multitude of commercial uses as mentioned in the Section 3 (General uses). The market value of these microorganisms is dependent on the production process, costs (energy and labor), geographic origin, certification, and type of processing chain. Based on business to business, value of Arthrospira platensis, a species mainly marketed for food and dietary supplements, ranges from 30 to $70 € \mathrm{~kg}^{-1}$ (d.w.). In contrast, its business to consumers value is $280 € \mathrm{~kg}^{-1}$ (higher value for small package sizes, finished products) [140]. Although there are many efforts to reduce the production costs of cyanobacteria, the European legislative framework is the most critical barrier that is limiting the industrial development of cyanobacteria. The most relevant legislative limitations have been well identified [141]: (i) few species can be grown compared to the wide biodiversity of species; (ii) the lack of genomic data and the risk of large-scale crop pollution; (iii) the complexity of administrative procedures for approving novel foods; (iv) limited access to both information and updates for cyanobacterial research and commercialization; (v) the lack of uniformity of legislation in EU countries. For instance, the regulation of cyanobacteria as fertilizers and biostimulants is currently not uniform from one country to another. EU Regulation 2019/1009 that will take effect in 2022 will open up the market for algae, microalgae and cyanobacteria, since organic fertilizers will no longer require marketing authorization, resulting in a great and beneficial impact for the agronomic sector [19]. Accordingly, there is an urgent need to update legislative knowledge on both cyanobacteria and microalgae, to create ISO (Carbon Footprint) certifications, and to establish model regulatory frameworks for importing and monitoring microorganism strains [141]. In addition, cyanobacteria are also identified as biological agents for biocontrol of pathogenic fungi and soil-borne diseases of plants [142]. Several compounds extracted from cyanobacteria with activity against pathogens have been investigated $[23,107,109]$ but have not yet been commercialized as plant protection products. The extracts are very promising for their low or no adverse effect on food and environmental safety and, therefore, they have a central role in the development of sustainable agriculture. This approach is also consistent with the European Regulation EC 1107/2009, concerning 
the placing of plant protection products on the market and repealing Council Directives 79/117/EEC and 91/414/EEC. However, no active substances namely "sea-algae extract" (in this group, no distinction is made between algae and cyanobacteria) is allowed as plant protection product for the placing on the market.

\section{Conclusions}

Cyanobacteria are a promising natural resource with potential applications in several fields. Their production has an overall low environmental impact, so cyanobacteria are an appealing renewable source of bioactive compounds and other fine chemicals. Nevertheless, the large variability of cyanobacteria in natural ecosystems makes these microorganisms a still unexplored field; specifically, genetic improvement studies on cyanobacteria with a view to eco-sustainable agriculture are lacking. This review will not only contribute to the basic knowledge of cyanobacteria, but will also further elucidate their role in the management of destructive fungal and oomycetes plant pathogens and in the plant biostimulation according to the latest scientific knowledge.

Supplementary Materials: The following are available online at https: / www.mdpi.com/article / 10.3390/horticulturae8010058/s1, Table S1: Promoting effects of cyanobacteria on agricultural plants following different kind of treatment method.

Author Contributions: Conceptualization, H.R. and R.R.; writing-original draft preparation, H.R., O.F., A.M.Q. and R.R.; writing-review and editing, H.R., O.F. A.M.Q., and R.R. All authors have read and agreed to the published version of the manuscript.

Funding: This research received no external funding.

Institutional Review Board Statement: This study did not require ethical approval.

Informed Consent Statement: Not applicable.

Acknowledgments: We thank Francesco Flamigni for drawing Figure 5.

Conflicts of Interest: The authors declare no conflict of interest.

\section{References}

1. Schopf, J.W. The fossil record of cyanobacteria. In Ecology of Cyanobacteria II; Whitton, B., Ed.; Springer: Dordrecht, The Netherlands, 2012; pp. 15-36.

2. Blankenship, R.E. Origin and early evolution of photosynthesis. Photosynth. Res. 1992, 33, 91-111. [CrossRef]

3. Buick, R. The antiquity of oxygenic photosynthesis: Evidence from stromatolites in sulphate-deficient archaean lakes. Science 1992, 255, 74-77. [CrossRef]

4. Barsanti, L.; Gualtieri, P. General Overview. In Algae: Anatomy, Biochemistry, and Biotechnology; Barsanti, L., Gualtieri, P., Eds.; CRC Press Taylor \& Francis: Boca Raton, FL, USA, 2005; pp. 1-6.

5. Dvořák, P.; Casamatta, D.A.; Hašler, P.; Jahodářová, E.; Norwich, A.R.; Poulíčková, A. Diversity of the Cyanobacteria. In Modern Topics in the Phototrophic Prokaryotes; Hallenbeck, P., Ed.; Springer: Cham, Switzerland, 2017; pp. 3-17.

6. Demoulin, C.F.; Lara, Y.J.; Cornet, L.; François, C.; Baurain, D.; Wilmotte, A.; Javaux, E.J. Cyanobacteria evolution: Insight from the fossil record. Free Radic. Biol. Med. 2019, 140, 206-223. [CrossRef]

7. Stal, L.J. Cyanobacteria: Diversity and versatility, clues to life in extreme environments. In Algae and Cyanobacteria in Extreme Environments; Seckbach, J., Ed.; Springer: Dordrecht, The Netherlands, 2007; Volume 11, pp. 661-682.

8. Whitton, B.A.; Potts, M. Ecology of Cyanobacteria II: Their Diversity in Space and Time; Kluwer Academic Publishers: Dordrecht, The Netherlands, 2012; pp. 1-13.

9. Kurmayer, R.; Deng, L.; Entfellner, E. Role of toxic and bioactive secondary metabolites in colonization and bloom formation by filamentous cyanobacteria Planktothrix. Harmful Algae 2016, 54, 69-86. [CrossRef] [PubMed]

10. Mazard, S.; Penesyan, A.; Ostrowski, M.; Paulsen, I.T.; Egan, S. Tiny microbes with a big impact: The role of cyanobacteria and their metabolites in shaping our future. Mar. Drugs 2016, 14, 97. [CrossRef] [PubMed]

11. Mantzouki, E.; Visser, P.M.; Bormans, M.; Ibelings, B.W. Understanding the key ecological traits of cyanobacteria as a basis for their management and control in changing lakes. Aquat. Ecol. 2016, 50, 333-350. [CrossRef]

12. Herrero, A.; Flores, E. The Cyanobacteria: Molecular Biology, Genomics and Evolution; Caister Academic Press: Sevilla, Spain, 2008; p. 484.

13. Boden, J.S.; Konhauser, K.O.; Robbins, L.J.; Sánchez-Baracaldo, P. Timing the evolution of antioxidant enzymes in cyanobacteria. Nat. Commun. 2021, 12, 4742. [CrossRef] 
14. Demay, J.; Bernard, C.; Reinhardt, A.; Marie, B. Natural products from cyanobacteria: Focus on beneficial activities. Mar. Drugs 2019, 17, 320. [CrossRef] [PubMed]

15. Shah, S.A.A.; Akhter, N.; Auckloo, B.N.; Khan, I.; Lu, Y.; Wang, K.; Wu, B.; Guo, Y.-W. Structural diversity, biological properties and applications of natural products from cyanobacteria. A review. Mar. Drugs 2017, 15, 354. [CrossRef]

16. Carpine, R.; Sieber, S. Antibacterial and antiviral metabolites from cyanobacteria: Their application and their impact on human health. Curr. Res. Biotechnol. 2021, 3, 65-81. [CrossRef]

17. Prasanna, R.; Nain, L.; Tripathi, R.; Gupta, V.; Chaudhary, V.; Middha, S.; Joshi, M.; Ancha, R.; Kaushik, B.D. Evaluation of fungicidal activity of extracellular filtrates of cyanobacteria-Possible role of hydrolytic enzymes. J. Basic Microbiol. 2008, 48, 186-194. [CrossRef]

18. Santini, G.; Biondi, N.; Rodolfi, L.; Tredici, M.R. Plant biostimulants from cyanobacteria: An emerging strategy to improve yields and sustainability in agriculture. Plants 2021, 10, 643. [CrossRef]

19. Berthon, J.-Y.; Michel, T.; Wauquier, A.; Joly, P.; Gerbore, J.; Filaire, E. Seaweed and microalgae as major actors of blue biotechnology to achieve plant stimulation and pest and pathogen-A review of the latest advances and future prospects. J. Agric. Sci. 2021, 1, 12. [CrossRef]

20. Righini, H.; Francioso, O.; Di Foggia, M.; Prodi, A.; Martel Quintana, A.; Roberti, R. Tomato seed biopriming with water extracts from Anabaena minutissima, Ecklonia maxima and Jania adhaerens as a new agro-ecological option against Rhizoctonia solani. Sci. Hortic. 2021, 281, 109921. [CrossRef]

21. Chaudhary, V.; Prasanna, R.; Nain, L.; Dubey, S.C.; Gupta, V.; Singh, R.; Jaggi, S.; Bhatnagar, A.K. Bioefficacy of novel cyanobacteriaamended formulations in suppressing damping off disease in tomato seedlings. World J. Microbiol. Biotechnol. 2012, 28, 3301-3310. [CrossRef] [PubMed]

22. Prasanna, R.; Chaudhary, V.; Gupta, V.; Babu, S.; Kumar, A.; Singh, R.; Shivay, Y.S.; Nain, L. Cyanobacteria mediated plant growth promotion and bioprotection against Fusarium wilt in tomato. Eur. J. Plant Pathol. 2013, 136, 337-353. [CrossRef]

23. Righini, H.; Francioso, O.; Di Foggia, M.; Martel Quintana, A.; Roberti, R. Assessing the potential of the terrestrial cyanobacterium Anabaena minutissima for controlling Botrytis cinerea on tomato fruits. Horticulturae 2021, 7, 210. [CrossRef]

24. Righini, H.; Somma, A.; Cetrullo, S.; D’Adamo, S.; Flamigni, F.; Martel Quintana, A.; Roberti, R. Inhibitory activity of aqueous extracts from Anabaena minutissima, Ecklonia maxima and Jania adhaerens on the cucumber powdery mildew pathogen in vitro and in vivo. J. Appl. Phycol. 2020, 32, 3363-3375. [CrossRef]

25. Koksharova, O.A.; Wolk, C.P. Genetic tools for cyanobacteria. Appl. Microbiol. Biotechnol. 2002, 58, $123-137$.

26. Wijffels, R.H.; Kruse, O.; Hellingwerf, K.J. Potential of industrial biotechnology with cyanobacteria and eukaryotic microalgae. Curr. Opin. Biotech. 2013, 24, 405-413. [CrossRef]

27. Balasubramaniam, V.; Gunasegavan, R.D.N.; Mustar, S.; Lee, J.C.; Mohd Noh, M.F. Isolation of industrial important bioactive compounds from microalgae. Molecules 2021, 26, 943. [CrossRef]

28. Masojídek, J.; Torzillo, G. Mass Cultivation of Freshwater Microalgae. In Encyclopedia of Ecology, 1st ed.; Jørgensen, S.E., Fath, B.D., Eds.; Elsevier B.V.: Amsterdam, The Netherlands, 2008; pp. 2226-2235.

29. Acién, F.G.; Molina, E.; Reis, A.; Torzillo, G.; Zittelli, G.C.; Sepúlveda, C.; Masojídek, J. Photobioreactors for the production of microalgae. In Microalgae-Based Biofuels and Bioproducts; Gonzales-Fernandez, C., Munoz, R., Eds.; Woodhead Publishing; Elsevier: Kidlington, UK, 2017; pp. 1-44.

30. Masojídek, J.; Ranglová, K.; Lakatos, G.E.; Silva Benavides, A.M.; Torzillo, G. Variables governing photosynthesis and growth in microalgae mass cultures. Processes 2021, 9, 820. [CrossRef]

31. Darvehei, P.; Bahri, P.A.; Moheimani, N.R. Model development for the growth of microalgae: A review. Renew. Sust. Energ. Rev. 2018, 97, 233-258. [CrossRef]

32. Show, K.Y.; Lee, D.J.; Chang, J.S. Algal biomass dehydration. Bioresour. Technol. 2013, 135, 720-729. [CrossRef]

33. Mohn, F.H. Improved technologies for the harvesting and processing of microalgae and their impact on production costs. In Microalgae for Food and Feed/Ergebn. Limnol; Soeder, C.J., Binsack, R., Eds.; Schweizerbart Science Publisher: Stuttgart, Germany, 1978; Volume II, pp. 228-253.

34. Ventura, S.P.M.; Nobre, B.P.; Ertekin, F.; Hayes, M.; Garciá-Vaquero, M.; Vieira, F.; Koc, M.; Gouveia, L.; Aires-Barros, M.R.; Palavra, A.M.F. Extraction of value-added compounds from microalgae. In Microalgae-Based Biofuels and Bioproducts; Gonzalez-Fernandez, C., Munoz, R., Eds.; Woodhead Publishing; Elsevier: Kidlington, UK, 2017; pp. 461-483.

35. Sanz, N.; García-Blanco, A.; Gavalás-Olea, A.; Loures, P.; Garrido, J.L. Phytoplankton pigment biomarkers: HPLC separation using a pentafluorophenyloctadecyl silica column. Methods Ecol. Evol. 2015, 6, 1199-1209. [CrossRef]

36. Desai, R.K.; Streefland, M.; Wijffels, R.H.; Eppink, M.H.M. Novel astaxanthin extraction from Haematococcus pluvialis using cell permeabilising ionic liquids. Green Chem. 2016, 18, 1261-1267. [CrossRef]

37. Benedetti, M.; Vecchi, V.; Barera, S.; Dall'Osto, L. Biomass from microalgae: The potential of domestication towards sustainable biofactories. Microb. Cell Fact. 2018, 17, 173. [CrossRef] [PubMed]

38. Favas, R.; Morone, J.; Martins, R.; Vasconcelos, V.; Lopes, G. Cyanobacteria and microalgae bioactive compounds in skin-ageing: Potential to restore extracellular matrix filling and overcome hyperpigmentation. J. Enzym. Inhib. Med. Chem. 2021, 36, 1829-1838. [CrossRef]

39. Fernandes, T.; Cordeiro, N. Microalgae as sustainable biofactories to produce high-value lipids: Biodiversity, exploitation, and biotechnological applications. Mar. Drugs 2021, 19, 573. [CrossRef] 
40. Pattnaik, S.; Singh, L. Cyanobacteria bioactive compound, their production and extraction with pharmaceutical applications-A review. Int. J. Curr. Microb. Appl. Sci. 2020, 9, 3394-3405. [CrossRef]

41. Kultschar, B.; Llewellyn, C. Secondary Metabolites in Cyanobacteria. In Secondary Metabolites-Sources and Applications; Vijayakumar, R., Ed.; IntechOpen: London, UK, 2018. [CrossRef]

42. Gademann, K.; Portmann, C. Secondary metabolites from cyanobacteria: Complex structures and powerful bioactivities. Curr. Org. Chem. 2008, 12, 326-341. [CrossRef]

43. Luesch, H.; Harrigan, G.G.; Goetz, G.; Horgen, F.D. The cyanobacterial origin of potent anticancer agents originally isolated from sea hares. Curr. Med. Chem. 2002, 9, 1791-1806. [CrossRef] [PubMed]

44. Burja, A.M.; Banaigs, B.; Abou-Mansour, E.; Burgess, J.G.; Wright, P.C. Marine cyanobacteria-A prolific source of natural products. Tetrahedron 2002, 57, 9347-9377. [CrossRef]

45. Jones, M.R.; Pinto, E.; Torres, M.A.; Dörr, F.; Mazur-Marzec, H.; Szubert, K.; Tartaglione, L.; Dell'Aversano, C.; Miles, C.O.; Beach, D.G.; et al. CyanoMetDB, a comprehensive public database of secondary metabolites from cyanobacteria. Water Res. 2021, 196, 117017. [CrossRef]

46. Nunnery, J.K.; Mevers, E.; Gerwick, W.H. Biologically active secondary metabolites from marine cyanobacteria. Curr. Opin. Biotechnol. 2010, 21, 787-793. [CrossRef] [PubMed]

47. Cabanillas, A.H.; Tena Pérez, V.; Maderuelo Corral, S.; Rosero Valencia, D.F.; Martel Quintana, A.; Ortega Doménech, M.; Rumbero Sánchez, Á. Cybastacines A and B: Antibiotic sesterterpenes from a Nostoc sp. cyanobacterium. J. Nat. Prod. 2018, 81, 410-413. [CrossRef] [PubMed]

48. Marahiel, M.A.; Essen, L.O. Nonribosomal peptide synthetases mechanistic and structural aspects of essential domains. Method Enzymol. 2009, 458, 337-351.

49. Llewellyn, C.A.; Kapoore, R.V.; Lovitt, R.W.; Greig, C.; Fuentes-Grünewald, C.; Kultschar, B. Deriving economic value from metabolites in cyanobacteria. In Grand Challenges in Algae Biotechnology; Hallmann, A., Rampelotto, P., Eds.; Springer: Cham, Switzerland, 2019; pp. 535-576.

50. Kapoore, R.V.; Wood, E.E.; Llewellyn, C.A. Algae biostimulants: A critical look at microalgal biostimulants for sustainable agricultural practices. Biotechnol. Adv. 2021, 49, 107754. [CrossRef]

51. Parwani, L.; Bhatt, M.; Singh, J. Potential biotechnological applications of cyanobacterial exopolysaccharides. Braz. Arch. Biol. Technol. 2021, 64, e21200401. [CrossRef]

52. Rosic, N.N. Recent advances in the discovery of novel marine natural products and mycosporine-like amino acid UV-absorbing compounds. Appl. Microbiol. Biotechnol. 2021, 105, 7053-7067. [CrossRef]

53. Morone, J.; Alfeus, A.; Vasconcelos, V.; Martins, R. Revealing the potential of cyanobacteria in cosmetics and cosmeceuticals-A new bioactive approach. Algal Res. 2019, 41, 101541. [CrossRef]

54. Vega, J.; Bonomi-Barufi, J.; Gómez-Pinchetti, J.L.; Figueroa, F.L. Cyanobacteria and red macroalgae as potential sources of antioxidants and UV radiation-absorbing compounds for cosmeceutical applications. Mar. Drugs 2020, 18, 659. [CrossRef] [PubMed]

55. Mitra, S.; Siddiqui, W.A.; Khandelwal, S. C-Phycocyanin protects against acute tributyltin chloride neurotoxicity by modulating glial cell activity along with its anti-oxidant and anti-inflammatory property: A comparative efficacy evaluation with $\mathrm{N}$-acetyl cysteine in adult rat brain. Chem. Biol. Interact. 2015, 238, 138-150. [CrossRef]

56. Vijayakumar, S.; Menakha, M. Pharmaceutical applications of cyanobacteria-A review. J. Acute Med. 2015, 5, 15-23. [CrossRef]

57. Tan, L.T.; Phyo, M.Y. Marine cyanobacteria: A source of lead compounds and their clinically-relevant molecular targets. Molecules 2020, 25, 2197. [CrossRef] [PubMed]

58. Castaneda, A.; Ferraz, R.; Vieira, M.; Cardoso, I.; Vasconcelos, V.; Martins, R. Bridging cyanobacteria to neurodegenerative diseases: A new potential source of bioactive compounds against Alzheimer's disease. Mar. Drugs 2021, 19, 343. [CrossRef]

59. Saad, M.H.; El-Fakharany, E.M.; Salem, M.S.; Sidkey, N.M. The use of cyanobacterial metabolites as natural medical and biotechnological tools: Review article. J. Biomol. Struct. Dyn. 2020, 8, 1-23. [CrossRef]

60. Van Apeldoorn, M.E.; van Egmond, H.P.; Speijers, G.J.A.; Bakker, G.J.I. Toxins of cyanobacteria. Mol. Nutr. Food Res. 2007, 51, 7-60. [CrossRef]

61. Carmichael, W.W. The toxins of cyanobacteria. Sci. Am. 1994, 270, 78-86. [CrossRef]

62. Kubickova, B.; Babica, P.; Hilscherová, K.; Šindlerová, L. Effects of cyanobacterial toxins on the human gastrointestinal tract and the mucosal innate immune system. Environ. Sci. Eur. 2019, 31, 31. [CrossRef]

63. Carmichael, W.W. Health effects of toxin-producing cyano-bacteria, “The CyanoHabs". Hum. Ecol. Risk Assess. 2001, 7, 1393-1407. [CrossRef]

64. Bláha, L.; Babica, P.; Maršálek, B. Toxins produced in cyanobacterial water blooms-Toxicity and risks. Interdisc. Toxicol. 2009, 2, 36-41. [CrossRef] [PubMed]

65. Corbel, S.; Mougin, C.; Bouaïcha, N. Cyanobacterial toxins: Modes of actions, fate in aquatic and soil ecosystems, phytotoxicity and bioaccumulation in agricultural crops. Chemosphere 2014, 96, 1-15. [CrossRef] [PubMed]

66. Metcalf, J.S.; Tischbein, M.; Cox, P.A.; Stommel, E.W. Cyanotoxins and the nervous system. Toxins 2021, 13, 660. [CrossRef] [PubMed]

67. Diez-Quijada, L.; Benítez-González, M.d.M.; Puerto, M.; Jos, A.; Cameán, A.M. Immunotoxic effects induced by microcystins and cylindrospermopsin: A review. Toxins 2021, 13, 711. [CrossRef] 
68. Machado, J.; Campos, A.; Vasconcelos, V.; Freitas, M. Effects of microcystin-LR and cylindrospermopsin on plant-soil systems: A review of their relevance for agricultural plant quality and public health. Environ. Res. 2017, 153, 191-204. [CrossRef]

69. Máthé, C.; M-Hamvas, M.; Vasas, G.; Garda, T.; Freytag, C. Subcellular alterations induced by cyanotoxins in vascular plants-A review. Plants 2021, 10, 984. [CrossRef]

70. M-Hamvas, M.; Vasas, G.; Beyer, D.; Nagylaki, E.; Máthé, C. Microcystin-LR, a cyanobacterial toxin, induces DNA strand breaks correlated with changes in specific nuclease and protease activities in white mustard (Sinapis alba) seedlings. Plants 2021, 10, 2045. [CrossRef]

71. Campos, A.; Redouane, E.M.; Freitas, M.; Amaral, S.; Azevedo, T.; Loss, L.; Máthé, C.; Mohamed, Z.A.; Oudra, B.; Vasconcelos, V. Impacts of microcystins on morphological and physiological parameters of agricultural plants: A review. Plants 2021, 10, 639. [CrossRef]

72. Zhang, Y.; Whalen, J.K.; Sauvé, S. Phytotoxicity and bioconcentration of microcystins in agricultural plants: Meta-analysis and risk assessment. Environ. Pollut. 2021, 272, 115966. [CrossRef]

73. Liang, C.; Wang, W. Response and recovery of rice (Oryza sativa) seedlings to irrigation with microcystin-contaminated water. Environ. Earth Sci. 2015, 73, 4573-4580. [CrossRef]

74. Abe, T.; Lawson, T.; Weyers, J.D.; Codd, G.A. Microcystin-LR inhibits photosynthesis of Phaseolus vulgaris primary leaves: Implications for current spray irrigation practice. New Phytol. 1996, 133, 651-658. [CrossRef]

75. Westphal, S.; Soll, J.; Vothknecht, U.C. A vesicle transport system inside chloroplasts. FEBS Lett. 2001, 506, 257-261. [CrossRef]

76. Máthé, C.; M-Hamvas, M.; Vasas, G. Microcystin-LR and cylindrospermopsin induced alterations in chromatin organization of plant cells. Mar. Drugs 2013, 11, 3689-3717. [CrossRef] [PubMed]

77. McElhiney, J.; Lawton, L.A.; Leifert, C. Investigations into the inhibitory effects of microcystins on plant growth, and the toxicity of plant tissues following exposure. Toxicon 2001, 39, 1411-1420. [CrossRef]

78. Babica, P.; Bláha, L.; Maršálek, B. Exploring the natural role of microcystins-A review of effects on photoautotrophic organisms. J. Phycol. 2006, 42, 9-20. [CrossRef]

79. Knogge, W. Fungal infection of plants. Plant Cell 1996, 8, 1711-1722. [CrossRef] [PubMed]

80. Dean, R.; Van Kan, J.A.L.; Pretorius, Z.A.; Hammond-Kosack, K.E.; Di Pietro, A.; Spanu, P.D.; Rudd, J.J.; Dickman, M.; Kahmann, R.; Ellis, J.; et al. The Top 10 fungal pathogens in molecular plant pathology. Mol. Plant Pathol. 2012, 13, 414-430. [CrossRef] [PubMed]

81. Gil-Serna, J.; Vázquez, C.; Patiño, B. Genetic regulation of aflatoxin, ochratoxin A, trichothecene, and fumonisin biosynthesis: A review. Int. Microbiol. 2020, 23, 89-96. [CrossRef]

82. Morales, H.; Marín, S.; Rovira, A.; Ramos, A.J.; Sanchis, V. Patulin accumulation in apples by Penicillium expansum during postharvest stages. Lett. Appl. Microbiol. 2007, 44, 30-35. [CrossRef]

83. Bertero, A.; Moretti, A.; Spicer, L.J.; Caloni, F. Fusarium molds and mycotoxins: Potential species-specific effects. Toxins 2018, 10, 244. [CrossRef] [PubMed]

84. Carris, L.M.; Little, C.R.; Stiles, C.M. Introduction to Fungi. 2012. Available online: https://www.apsnet.org/edcenter/ disandpath/fungalasco/intro/Pages/IntroFungi.aspx (accessed on 15 October 2021).

85. Barberis, C.L.; Dalcero, A.M.; Magnoli, C.E. Evaluation of aflatoxin $\mathrm{B}_{1}$ and ochratoxin A in interacting mixed cultures of Aspergillus sections Flavi and Nigri on peanut grains. Mycotoxin Res. 2012, 28, 149-156. [CrossRef] [PubMed]

86. Gnat, S.; Łagowski, D.; Nowakiewicz, A.; Dylag, M. A global view on fungal infections in humans and animals: Opportunistic infections and microsporidioses. J. Appl. Microbiol. 2021, 131, 2095-2113. [CrossRef] [PubMed]

87. Jenkins, S.; Taylor, A.; Jackson, A.C.; Armitage, A.D.; Bates, H.J.; Mead, A.; Harrison, R.J.; Clarkson, J.P. Identification and expression of secreted in xylem pathogenicity genes in Fusarium oxysporum f. sp. pisi. Front. Microbiol. 2021, 12, 593140. [CrossRef]

88. Michielse, C.B.; Rep, M. Pathogen profile update: Fusarium oxysporum. Mol. Plant Pathol. 2009, 10, 311-324. [CrossRef] [PubMed]

89. Agrios, G. Plant Pathology, 5th ed.; Elsevier Academic Press: San Diego, CA, USA, 2005; p. 952.

90. Batista, B.G.; de Chaves, M.A.; Reginatto, P.; Saraiva, O.J.; Fuentefria, A.M. Human fusariosis: An emerging infection that is difficult to treat. Rev. Soc. Bras. Med. Trop. 2020, 53, e20200013. [CrossRef]

91. Lamour, K.H.; Stam, R.; Jupe, J.; Huitema, E. The oomycete broad-host-range pathogen Phytophthora capsici. Mol. Plant. Pathol. 2012, 13, 329-337. [CrossRef]

92. Baker, K.F. Types of Rhizoctonia diseases and their occurrence. In Rhizoctonia solani: Biology and Pathology; Parmeter, J.R., Jr., Ed.; University of California Press: Berkeley, CA, USA, 1970; pp. 125-148.

93. Fillinger, S.; Elad, Y. Botrytis-The Fungus, the Pathogen and Its Management in Agricultural Systems; Springer International Publishing: Cham, Switzerland, 2016; p. 486.

94. Pérez-García, A.; Romero, D.; Fernández-Ortuño, D.; López-Ruiz, F.; De Vicente, A.; Tores, J.A. The powdery mildew fungus Podosphaera fusca (synonym Podosphaera xanthii), a constant threat to cucurbits. Mol. Plant Pathol. 2009, 10, 153-160. [CrossRef]

95. Keinath, A.P.; DuBose, V.B. Evaluation of fungicides for prevention and management of powdery mildew on watermelon. Crop Prot. 2004, 23, 35-42. [CrossRef]

96. Boddy, L. Pathogens of autotrophs. In The Fungi, 3rd ed.; Watkinson, S.C., Boddy, L., Money, N.P., Eds.; Academic Press: London, UK, 2016; pp. 245-292.

97. Marrez, D.A.; Sultan, Y.Y. Antifungal activity of the cyanobacterium Microcystis aeruginosa against mycotoxigenic fungi. J. Appl. Pharm. Sci. 2016, 6, 191-198. [CrossRef] 
98. Shishido, T.K.; Humisto, A.; Jokela, J.; Liu, L.; Wahlsten, M.; Tamrakar, A.; Fewer, D.P.; Permi, P.; Andreote, A.P.D.; Fiore, M.F.; et al. Antifungal compounds from cyanobacteria. Mar. Drugs 2015, 13, 2124-2140. [CrossRef]

99. El-Sheekh, M.M.; Osman, M.E.H.; Dyab, M.A.; Amer, M.S. Production and characterization of antimicrobial active substance from the cyanobacterium Nostoc muscorum. Environ. Toxicol. Phar. 2006, 21, 42-50. [CrossRef]

100. Pawar, S.T.; Puranik, P.R. Screening of terrestrial and freshwater halotolerant cyanobacteria for antifungal activities. World J. Microbiol. Biotechnol. 2008, 24, 1019-1025. [CrossRef]

101. Kim, J.D. Screening of cyanobacteria (blue-green algae) from rice paddy soil for antifungal activity against plant pathogenic fungi. Microbiology 2006, 34, 138-142. [CrossRef]

102. Biondi, N.; Piccardi, R.; Margheri, M.C.; Rodolfi, L.; Smith, G.D.; Tredici, M.R. Evaluation of Nostoc strain ATCC 53789 as a potential source of natural pesticides. Appl. Environ. Microbiol. 2004, 70, 3313-3320. [CrossRef]

103. Alwathnani, H.A.; Perveen, K. Biological control of Fusarium wilt of tomato by antagonist fungi and cyanobacteria. Afr. J. Biotechnol. 2012, 11, 1100-1105. [CrossRef]

104. Kim, J.; Kim, J.-D. Inhibitory effect of algal extracts on mycelial growth of the tomato-wilt pathogen, Fusarium oxysporum $\mathrm{f}$. sp. lycopersici. Mycobiology 2008, 36, 242-248. [CrossRef]

105. Gupta, V.; Prasanna, R.; Natarajan, C.; Srivastava, A.K.; Sharma, J. Identification, characterization, and regulation of a novel antifungal chitosanase gene (cho) in Anabaena spp. Appl. Environ. Microbiol. 2010, 76, 2769-2777. [CrossRef]

106. Osman, M.E.A.H.; El-Sheekh, M.M.; Metwally, M.A.; Ismail, A.E.W.A.; Ismail, M.M. Antagonistic activity of some fungi and cyanobacteria species against Rhizoctonia solani. Int. J. Plant Pathol. 2011, 2, 101-114. [CrossRef]

107. Righini, H.; Francioso, O.; Di Foggia, M.; Martel Quintana, A.; Roberti, R. Preliminary study on the activity of phycobiliproteins against Botrytis cinerea. Mar. Drugs 2020, 18, 600. [CrossRef]

108. Moreno, A.B.; Martínez del Pozo, Á.; Borja, M.; San Segundo, B. Activity of the antifungal protein from Aspergillus giganteus against Botrytis cinerea. Phytopathology 2003, 93, 1344-1353. [CrossRef]

109. Righini, H.; Baraldi, E.; García Fernández, Y.; Martel Quintana, A.; Roberti, R. Different Antifungal Activity of Anabaena sp., Ecklonia sp., and Jania sp. against Botrytis cinerea. Mar. Drugs 2019, 17, 299. [CrossRef]

110. Roberti, R.; Galletti, S.; Burzi, P.L.; Righini, H.; Cetrullo, S.; Perez, C. Induction of defence responses in zucchini (Cucurbita pepo) by Anabaena sp. water extract. Biol. Control 2015, 82, 61-68. [CrossRef]

111. Kumar, M.; Prasanna, R.; Bidyarani, N.; Babu, S.; Mishra, B.K.; Kumar, A.; Adak, A.; Jauhari, S.; Yadav, K.; Singh, R.; et al. Evaluating the plant growth promoting ability of thermotolerant bacteria and cyanobacteria and their interactions with seed spice crops. Sci. Hortic. 2013, 164, 94-101. [CrossRef]

112. Belton, S.; McCabe, P.F.; Ng, C.K.Y. The cyanobacterium, Nostoc punctiforme can protect against programmed cell death and induce defence genes in Arabidopsis thaliana. J. Plant Interact. 2021, 16, 64-74. [CrossRef]

113. Zheng, J.; Zhang, Z.; Tong, T.; Fang, Y.; Zhang, X.; Niu, C.; Li, J.; Wu, Y.; Xue, D.; Zhang, X. Genome-wide identification of wrky gene family and expression analysis under abiotic stress in barley. Agronomy 2021, 11, 521. [CrossRef]

114. Thapa, S.; Prasanna, R.; Ramakrishnan, B.; Mahawar, H.; Bharti, A.; Kumar, A.; Velmourougane, K.; Shivay, Y.S.; Kumar, A. Microbial inoculation elicited changes in phyllosphere microbial communities and host immunity suppress Magnaporthe oryzae in a susceptible rice cultivar. Physiol. Mol. Plant Pathol. 2021, 114, 101625. [CrossRef]

115. Priya, H.; Prasanna, R.; Ramakrishnan, B.; Bidyarani, N.; Babu, S.; Thapa, S.; Renuka, N. Influence of cyanobacterial inoculation on the culturable microbiome and growth of rice. Microbiol. Res. 2015, 171, 78-89. [CrossRef]

116. Le Mire, G.; Siah, A.; Marolleau, B.; Gaucher, M.; Maumené, C.; Brostaux, Y.; Massart, S.; Brisset, M.N.; Jijakli, M.H. Evaluation of $\lambda$-carrageenan, CpG-ODN, glycine betaine, Spirulina platensis, and ergosterol as elicitors for control of Zymoseptoria tritici in wheat. Phytopathology 2019, 109, 409-417. [CrossRef]

117. Rachidi, F.; Benhima, R.; Kasmi, Y.; Sbabou, L.; El Arroussi, H. Evaluation of microalgae polysaccharides as biostimulants of tomato plant defense using metabolomics and biochemical approaches. Sci. Rep. 2021, 11, 930. [CrossRef]

118. Chiaiese, P.; Corrado, G.; Colla, G.; Kyriacou, M.C.; Rouphael, Y. Renewable sources of plant biostimulation: Microalgae as a sustainable means to improve crop performance. Front. Plant Sci. 2018, 9, 1782. [CrossRef]

119. Sharma, S.B.; Sayyed, R.Z.; Trivedi, M.H.; Gobi, T.A. Phosphate solubilizing microbes: Sustainable approach for managing phosphorus deficiency in agricultural soils. Springerplus 2013, 2, 587. [CrossRef]

120. Li, J.; Li, C.; Smith, S.M. Hormone Metabolism and Signaling in Plants; Academic Press Elsevier: London, UK, $2017 ;$ p. 597.

121. Karthikeyan, N.; Prasanna, R.; Sood, A.; Jaiswal, P.; Nayak, S.; Kaushik, B.D. Physiological characterization and electron microscopic investigation of cyanobacteria associated with wheat rhizosphere. Folia Microbiol. 2009, 54, 43-51. [CrossRef]

122. Maqubela, M.P.; Mnkeni, P.N.S.; Malam Issa, O.; Pardo, M.T.; D'Acqui, L.P. Nostoc cyanobacterial inoculation in South African agricultural soils enhances soil structure, fertility, and maize growth. Plant Soil 2009, 315, 79-92. [CrossRef]

123. Rezanka, T.; Palyzová, A.; Sigler, K. Isolation and identification of siderophores produced by cyanobacteria. Folia Microbiol. 2018, 63, 569-579. [CrossRef]

124. Shukia, S.P.; Singh, J.S.; Kashyap, S.; Giri, D.D.; Kashyap, A.K. Antarctic cyanobacteria as a source of phycocyanin: An assessment. Indian J. Mar. Sci. 2008, 37, 446-449.

125. Godlewska, K.; Michalak, I.; Pacyga, P.; Baśladyńska, S.; Chojnacka, K. Potential applications of cyanobacteria: Spirulina platensis filtrates and homogenates in agriculture. World J. Microbiol. Biotechnol. 2019, 35, 80. [CrossRef] 
126. Markets and Markets. Available online: https://www.marketsandmarkets.com/Market-Reports/biostimulant-market-1081.html (accessed on 9 October 2021).

127. Arnau, L. Techno-Economic Feasibility Study for the Production of Microalgae Based Plant Biostimulant. Master's Thesis, KTH, Royal Institute of Technology School of Chemical Science and Engineering, Stockholm, Sweden, 2016.

128. El Boukhari, M.E.M.E.; Barakate, M.; Bouhia, Y.; Lyamlouli, K. Trends in seaweed extract based biostimulants: Manufacturing process and beneficial effect on soil-plant systems. Plants 2020, 9, 359. [CrossRef]

129. Siddiki, S.Y.A.; Mofijur, M.; Kumar, S.P.; Ahmed, S.F.; Inayat, A.; Kusumo, F.; Badruddin, I.A.; Yunus Khan, T.M.; Nghiem, L.D.; Ong, H.C.; et al. Microalgae biomass as a sustainable source for biofuel, biochemical and biobased value-added products: An integrated biorefinery concept. Fuel 2022, 307, 121782. [CrossRef]

130. Romero Villegas, G.I.; Fiamengo, M.; Acién Fernández, F.G.; Molina Grima, E. Outdoor production of microalgae biomass at pilot-scale in seawater using centrate as the nutrient source. Algal Res. 2017, 25, 538-548. [CrossRef]

131. Aghofack-Nguemezi, J.; Schinzoumka, P.A.; Tatchago, V. Effects of extracts or powder of Jatropha curcas and Spirulina platensis on the growth and development of tomato plant. J. Appl. Biosci. 2015, 90, 8413-8420. [CrossRef]

132. Renuka, N.; Guldhe, A.; Prasanna, R.; Singh, P.; Bux, F. Microalgae as multi-functional options in modern agriculture: Current trends, prospects and challenges. Biotechnol. Adv. 2018, 36, 1255-1273. [CrossRef]

133. Mógor, Á.F.; Ördög, V.; Pereira Lima, G.P.; Molnár, Z.; Mógor, G. Biostimulant properties of cyanobacterial hydrolysate related to polyamines. J. Appl. Phycol. 2018, 30, 453-460. [CrossRef]

134. Supraja, K.V.; Behera, B.; Balasubramanian, P. Efficacy of microalgal extracts as biostimulants through seed treatment and foliar spray for tomato cultivation. Ind. Crops Prod. 2020, 151, 112453.

135. Toribio, A.J.; Suárez-Estrella, F.; Jurado, M.M.; López, M.J.; López-González, J.A.; Moreno, J. Prospection of cyanobacteria producing bioactive substances and their application as potential phytostimulating agents. Biotechnol. Rep. 2020, 26, e00449. [CrossRef]

136. Singh, S. A review on possible elicitor molecules of cyanobacteria: Their role in improving plant growth and providing tolerance against biotic or abiotic stress. J. Appl. Microbiol. 2014, 117, 1221-1244. [CrossRef]

137. Žižková, E.; Kubeš, M.; Dobrev, P.I.; Přibyl, P.; Šimura, J.; Zahajská, L.; Drábková, L.Z.; Novák, O.; Motyka, V. Control of cytokinin and auxin homeostasis in cyanobacteria and algae. Ann. Bot. 2017, 119, 151-166. [CrossRef]

138. Bareke, T. Biology of seed development and germination physiology. Adv. Plants Agric. Res. 2018, 8, 336-346. [CrossRef]

139. Barone, V.; Baglieri, A.; Stevanato, P.; Broccanello, C.; Bertoldo, G.; Bertaggia, M.; Cagnin, M.; Pizzeghello, D.; Moliterni, V.M.C.; Mandolino, G.; et al. Root morphological and molecular responses induced by microalgae extracts in sugar beet (Beta vulgaris L.). J. Appl. Phycol. 2017, 30, 1061-1071. [CrossRef]

140. Araújo, R.; Vázquez Calderón, F.; Sánchez López, J.; Azevedo, I.C.; Bruhn, A.; Fluch, S.; Garcia Tasende, M.; Ghaderiardakani, F.; Ilmjärv, T.; Laurans, M.; et al. Current status of the algae production industry in Europe: An emerging sector of the blue bioeconomy. Front. Mar. Sci. 2021, 7, 626389. [CrossRef]

141. Rumin, J.; Gonçalves de Oliveira Junior, R.; Bérard, J.-B.; Picot, L. Improving microalgae research and marketing in the European Atlantic area: Analysis of major gaps and barriers limiting sector development. Mar. Drugs 2021, 19, 319. [CrossRef]

142. Lee, S.-M.; Ryu, C.-M. Algae as new kids in the beneficial plant microbiome. Front. Plant Sci. 2021, 12, 599742. [CrossRef] 